\title{
ECONOMIC FEASIBILITY \\ OF SOLAR-THERMAL INDUSTRIAL APPLICATIONS \\ AND SELECTED CASE STUDIES
}

\author{
Anita Montelione \\ David Boyd \\ Mike Branz \\ December 1981
}

NOTICE

PORTIONS OF THIS REPORT ARE IIIEGIBIE. It copy top

prepared for

\section{U.S. DEPARTMENT OF ENERGY}

under contract number DE-AC02-79CS30166

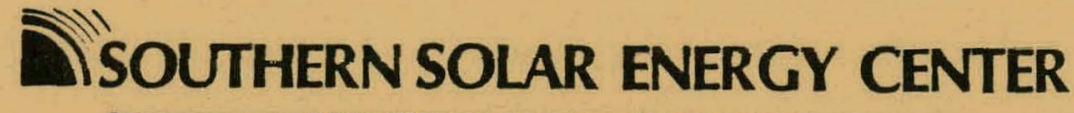

OPERATED WITH SUPPORT FROM THE U.S. DEPARTMENT OF ENERGY

61 PERAMETER PARK 


\section{DISCLAIMER}

This report was prepared as an account of work sponsored by an agency of the United States Government. Neither the United States Government nor any agency Thereof, nor any of their employees, makes any warranty, express or implied, or assumes any legal liability or responsibility for the accuracy, completeness, or usefulness of any information, apparatus, product, or process disclosed, or represents that its use would not infringe privately owned rights. Reference herein to any specific commercial product, process, or service by trade name, trademark, manufacturer, or otherwise does not necessarily constitute or imply its endorsement, recommendation, or favoring by the United States Government or any agency thereof. The views and opinions of authors expressed herein do not necessarily state or reflect those of the United States Government or any agency thereof. 


\section{DISCLAIMER}

Portions of this document may be illegible in electronic image products. Images are produced from the best available original document. 


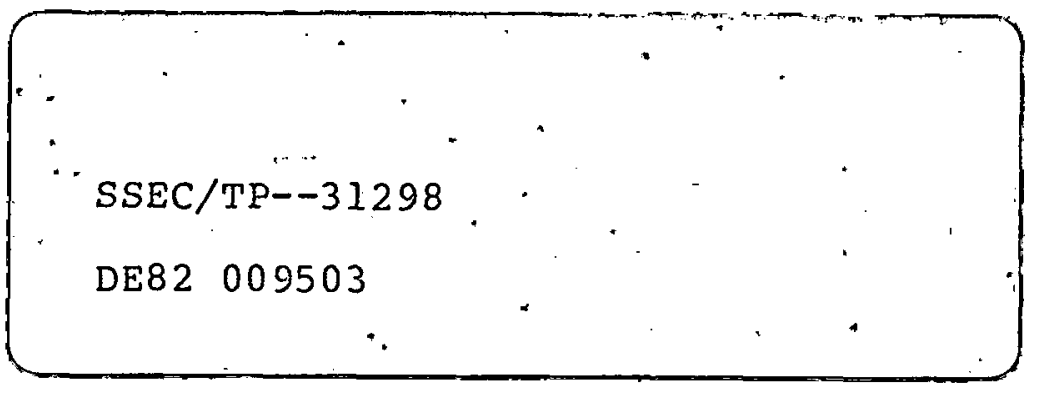

DISCLAIMER

This report was prepared as an account of work sponsored by the Southern Solar Energy Center, a contractor of the United States Government. Neither the Southern Solar Energy Center, the United States Government, nor any agency thereof, nor any of their employees, makes any warranty, express or implied, or assumes any legal liability or responsibility for the accuracy, completeness, or usefulness of any information, apparatus, product, or process disclosed, or represents that its use would not infringe privately owned rights. References herein to any specific comnercial product, process, or service by trade name, trademark, manufacturer, or otherwise, does not necessarily consticute or imply its endorsement, recomendation, or favoring by the Southern Solar Energy Center, the United States Government, or any agency thereof. The views and opinions of authors expressed herein do not necessarily state or reflect those of the Southern Solar Energy Center, the United States Government, nor any agency thereof.

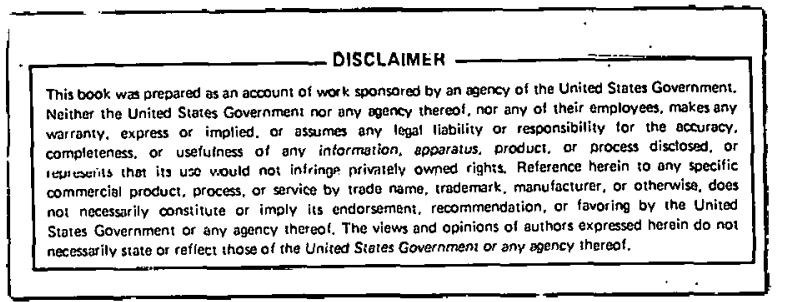


ECONOMIC FEASIBILITY OF SOLAR THERMAL INDUSTRIAL APPLICATIONS AND SELECTED CASE STUDIES

Anita Montelione

David Boyd

Mike Branz

December 1981 
In 1981, the Southern Solar Energy Center contracted with Georgia Institute of Technology, North Carolina State University, and Texas A\&M University to survey and assess the potential for Solar Industrial Process Heat (IPH) applications in the southern United States. Among the industries studied, the food processing and textile industries were viewed as likely candidates for the near-term application of solar thermal technology, since these industries require large amounts of hot water, hot air, and low-pressure steam, which are readily achievable with existing solar energy technologies.

The results of those case studies indicated that unfavorable economics and not technical deficiencies were the primary barrier to the implementation of solar IPH in these plants. Before further conclusions and decisions were made it was decided that several case studies be selected from each of the three reports and a standardized economic evaluation be employed. The economic criteria chosen were based on cost benefit analysis and included net present value, payback period, internal rate of return, and annualized cost. Acknowledging the dynamic nature of several parameters, a sensitivity analysis illustrating the responsiveness of the net present value to these parameters was performed. Also investigated were the effects the new depreciation schedule as described in the Economic Recovery Tax Act of 1981 would have on the economics.

The following conclusions can be drawn for the systems analyzed:

- The flat plate system in Georgia and the evacuated tube system in North Carolina, as defined, are economically feasible today.

- The shallow solar pond system in North Carolina recovers its initial cash outlay in less than three years; however, its net present value over 15 years is slightiy negative.

- The evacuated tube system in Georgia and the parabolic trough system in Texas will become economically feasible in roughly five and eight years respectively.

- The Economic Recovery Tax Act of 1981 significantly improves the economics of all systems in the near term by redistributing the depreciation allowance over a shorter time period.

- The net present value is most sensitive to changes in the collector cost, fuel escalation rates, and tax credits.

The analyses were performed based on the current economic climate. If deregulation of natural gas occurs the current natural gas price forecast would be revised upward thereby increasing the economic attractiveness of a solar IPH system. 


\section{ABSTRACT}

This report assesses the economic feasibility of utilizing solar energy to augment an existing fossil fuel system to generate industrial process heat. Several case studies in the textile and food processing industries in the southern United States were analyzed. Sensitivity analyses were performed, and comparisons illustrating the effects of the Economic Recovery Tax Act of 1981 were made. The economic desirability of the proposed solar systems varied with the type of system selected, location of the facility, state tax credits, and type of fuel displaced. For those systems presently not economical, the projected time to economic feasibility was ascertained. 


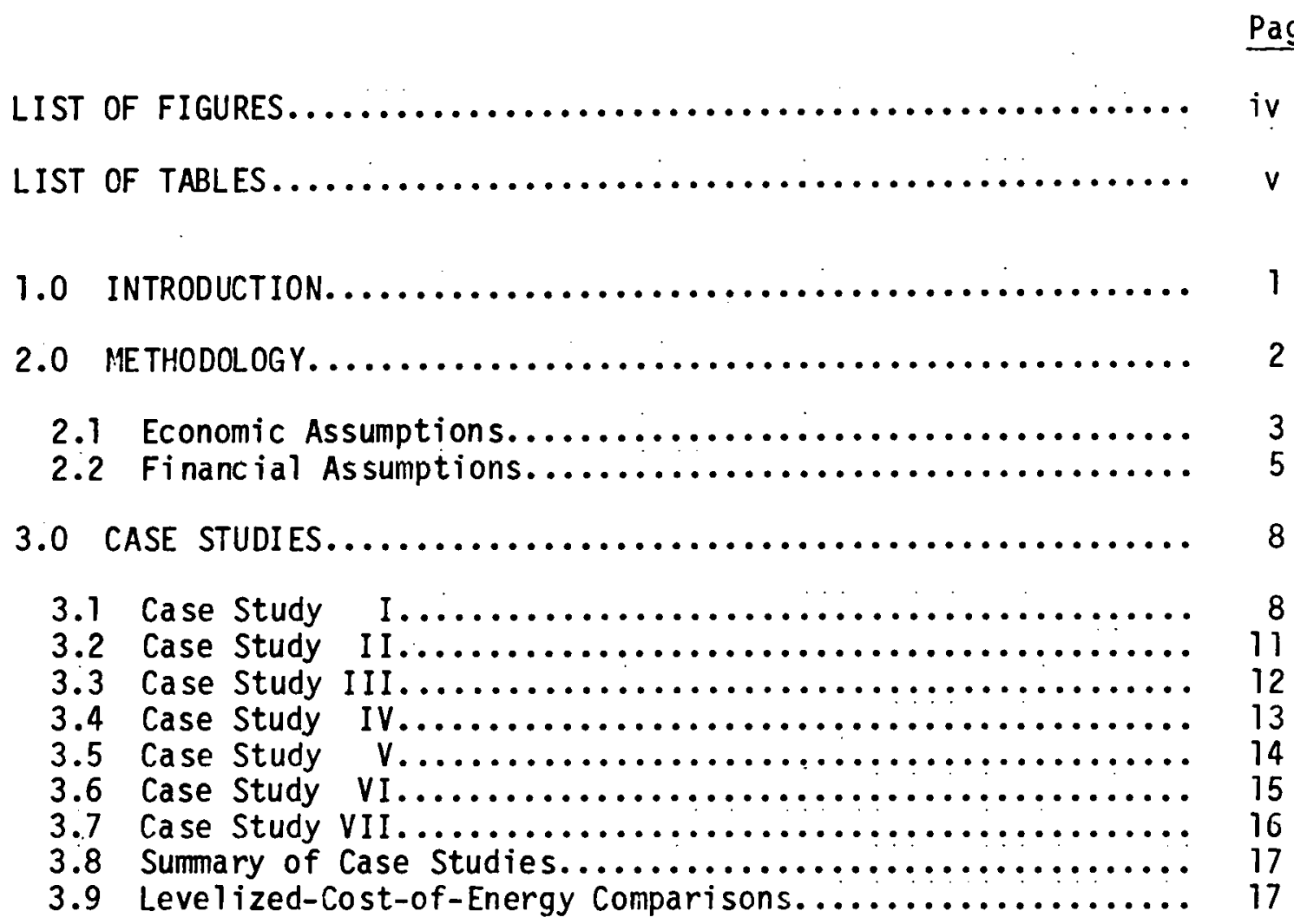

4.0 SENSITIVITY ANALYSES.......................

4.1 Fuel Price Projections Analysis.................. 21

4.1.1 Flat Plate Collector System, Case Study I, System I.. 21

4.1.2 Evacuated Tube System, Case Study II.............. 21

4.1.3 Shallow Solar Pond System, Case Study IV, System I... 23

4.1.4 Parabolic Trough System, Case Study VII........... 23

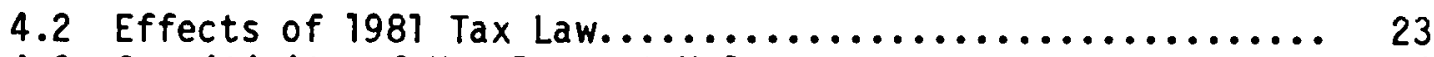

4.3 Sensitivity of Het Present Value.................. 26

5.0 CONCLUSIONS............................... 32

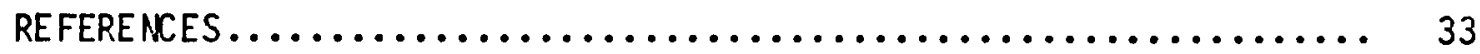

APPENDIX A: SAMPLE RUN OF WOOD 4 , VERSION $2 \ldots \ldots \ldots \ldots \ldots \ldots \ldots \ldots . . \ldots$

APPENDIX B: NET CASH FLOW TABLES.................. 41 


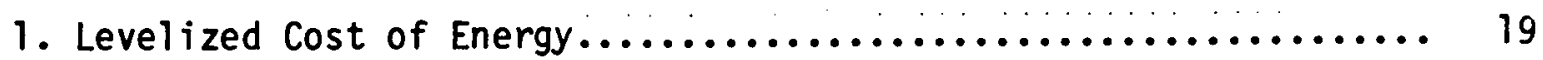

2. Breakeven Analysis vs. Natural Gas Price Forecasts - Georgia.... 22

3. Breakeven Analysis vs. Residual (\#6) Fuel 0il Price Forecasts North Carolina.......................................... 24

4. Breakeven Analysis vs. Natural Gas Price Forecasts - Texas...... 25

5. Sensitivity of Net Present Value - Flat Plate System......... 27

6. Sensitivity of Net Present Value - Evacuated Tube System........ 28

7. Sensitivity of Net Present Value - Shallow Solar Pond System..... 30

8. Sensitivity of Net Present Value - Parabolic Trough System...... 31 
Page

I. Economic Parameters........................... 4

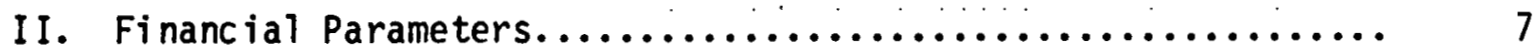

III. Net Cash Flow for Case Study I, System I............... 9

IV. Summary of Case Studies....................... 18

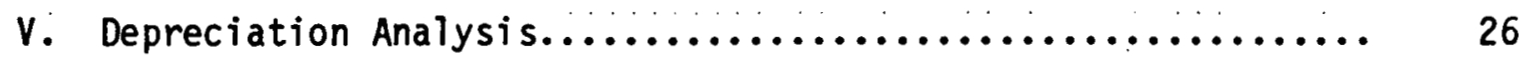

VI. Net Cash Flow for Case Study I, System II.............. 42

VII. Net Cash Flow for Case Study II.................... 43

VIII. Net Cash Flow for Case Study III................... 44

IX. Net Cash Flow for Case Study IV, System I............. 45

X. Net Cash Flow for Case Study IV, System II $\ldots \ldots \ldots \ldots \ldots \ldots \ldots .46$

XI. Net Cash Flow for Case Study $V \ldots \ldots \ldots \ldots \ldots \ldots \ldots \ldots \ldots \ldots \ldots \ldots \ldots . . \ldots 7$

XII. Net Cash Flow for Case Study VI...................... 48

XIII. Net Cash Flow for Case Study VII.................... 49 


\subsection{INTRODUCTION}

In 1981, the Southern Solar Energy Center contracted with Georgia Institute of Technology, North Carolina State University, ${ }^{2}$ and Texas A\&M University ${ }^{3}$ to survey and assess the potential for solar Industrial Process Heat (IPH) applications in the southern United States. Among the industries studied, the food processing and textile industries were viewed as likely candidates for the near-term application of solar thermal technology, since these require large amounts of hot water, hot air, and low-pressure steam, which are readily achievable with existing solar energy technologies.

The results of those case studies indicated that unfavorable economics and not technical deficiencies were the primary barrier to the implementation of solar IPH in these plants. Before further conclusions and decisions were made it was decided that several case studies be selected from each of the three reports and a standardized economics evaluation be employed. Acknowledging the dynamic nature of several parameters, a sensitivity analysis would be performed illustrating which parameters most directly influence the economic viability of solar IPH applications. Also considered desirable was to ascertain the projected time to economic feasibility. This study was undertaken to accomplish the above objectives.

Concurrently, tax laws changed, and the effect of the new depreciation schedules as prescribed in the Economic Recovery Tax Act of 1981 was assessed. This report defines the economic methodology employed in analyzing the selected case studies and discusses the results of the analyses. 


\subsection{METHODOLOGY}

There are several economic criteria that can be employed to evaluate alternative investment decisions. The most common methods are based on cost-benefit analysis (CBA). CBA is a systematic evaluation of a project to determine whether, and to what extent, its benefits outweigh its costs. The evaluation is based on economic measures of the value of a project and may be based on net present value, pay-back, internal rate of return (IRR), and annualized cost. For this project these four methods of evaluation are employed. The following paragraphs define these four measures of economic worth.

The net present value (NPV) of a project is a single number representing the value of a stream of future costs and benefits discounted to the present. Mathematically, the net present value of a project having costs (C) and benefits (B) now and through $H$ future time periods is

$$
\begin{aligned}
N P V & =B_{0}-C_{0}+\frac{B_{1}-C_{1}}{T+d)^{1}}+\frac{B_{2}-C_{2}}{(T+d)^{2}}+\cdots+\frac{B_{H}-C_{H}}{(T+d) \cdot H} \\
& =\sum_{t=0}^{H} \frac{B_{t}-C_{t}}{(T+d)^{t}}
\end{aligned}
$$

where $B_{t}=$ benefits in time period $t$,

$C_{t}=$ costs in time period $t$,

d $=$ discount rate, and

$H \quad=$ time horizon (generally taken as the economic lifetime of the project).

In this study the NPV of choosing the alternative scenario (solar-fossil hybrid system) over the baseline scenario (continuing with the existing fossil. system) is the NPV of the differences between the benefits and costs of the two scenarios. This is expressed as:

$$
\begin{aligned}
N P V & =\sum_{t=0}^{H} \frac{B_{t}-C_{t}}{(1+d) t}, \text { but now } \\
B_{t}= & \begin{array}{c}
\text { incremental savings with solar fossil systcm rclative to. } \\
\text { conventional fossil system, for year } t
\end{array} \\
C_{t}= & \begin{array}{c}
\text { incremental costs associated with solar-fossil system relative to } \\
\text { conventional fossil system, for year } t
\end{array}
\end{aligned}
$$

The payback of the initial investment is the length of time required to recover the initial investment from the net cash flows produced by the investment. This differs from simple payback (cost divided by first-year savings) in that it includes depreciation, and operating and fuel costs escalation. 
The payback of the total investment is the length of time required to recover the initial investment and to pay the remaining loan balance from the net cash flows produced by the investment. The net cash flows include depreciation and operating and fuel costs escalation in their calculations.

The internal rate of return is that rate of discounting the future that equates the initial cost and the sum of the future discounted net benefits. It is similar to compound interest in reverse. It discounts the cash flows arising from an investment at a rate that equates the cash flows to the present value of the initial investment.

The annualized (levelized) cost of energy is another basis for comparison. It transforms a fluctuating actual stream of costs to an equivalent uniform stream. This is done by calculating the present worth of the original series of costs, multiplying it by the capital recovery factor, then dividing this product by the annual energy output. In this study, the levelized cost of energy (\$/MMBtu) produced by fossil fuel is compared with the levelized cost of energy produced by solar with a fossil backup.

Industries that have a high degree of uncertainity concerning the future and are interested in their cash position and borrowing commitments would have a tendency to evaluate projects based on the payback period. However, basing decisions on this method ignores the time value of money and the cash flow after the payback period. Incorporating a life-cycle cost analysis and the time value of money into the decision process would mean evaluating the project based on the net present value, annualized cost, or internal rate of return method.

In these three methods a comparison is made between the existing system and the alternative system; if the projects meet the criteria established, it is accepted.

Since values for some parameters must often be estimated, an important aspect of any $C B A$ is the sensitivity analysis. This illustrates the responsiveness of the dependent variable such as the net present value to changes in the parameters. For this study the impact on the net present value and payback period of changes in capital cost, fuel cost, tax credit, and depreciation schedule is illustrated.

To assist in the evaluation a computer program known as WOOD 4 (Version 2) was adapted. This is an interactive program that determines the economic attractiveness of an investment based on life-cycle costs resulting from comparing an alternative energy system (in this case a solar-fossil system) to an energy system fired with oil or natural gas. The details of the program and an illustration of a sample case study appear in Appendix $A$.

\subsection{Ec onomic As sumptions}

The economic parameters consist of the various costs involved in retrofitting the existing fossil plant with a solar system (Table 1). The basic and most costly item of equipment is the collector. This accounts for 


\section{TABLE I}

Economic Parameters

Parameter (Dimensions)

Baseline Value

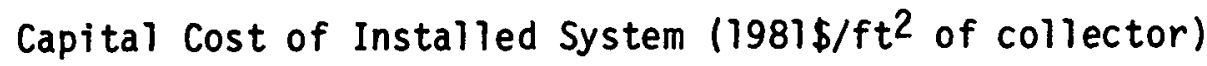

- Flat Plate

- Evacuated Tube 35

- Parabolic Trough

45

- Shallow Solar Pond

50

20

First-Year 0 \& M Cost (\% of Capital Cost) 2

0. \& M Escalation Rate (\%)

12.2

Operating Life (Years)

- Flat Plate, Evacuated Tube, Parabolic Trough 20

- Shallow Solar Pond 15

Equity Capital (\% of Capital Cost) 30

$\begin{array}{ll}\text { Loan Period (Years) } & 10\end{array}$

Loan Interest Rate (\%) 17

Fuel Escalation Rate* (Annual \%)

- Natural Gas
$1982-1992$
19.4
$1992-2002$
16.7

- Residual 0il

$1982-1992$

15.5

$1992-2002$

15.0

* Assuming a nominal inflation rate of $12 \%$. 
approximately $35 \%$ of the total cost. 4 The remaining $65 \%$ includes the support structure, piping, ductwork, insulation, electrical controls, and other auxiliary equipment. Cost of storage is not considered in the case studies evaluated, nor is that of the land necessary to house the collectors.

In addition to the capital cost there exists an annual maintenance cost. This includes the cost of cleaning and repairing the collectors as well as servicing the other equipment. Most manufacturers estimate annual operating and maintenance cost to be approximately $2 \%$ of capital cost for the early years of the system's life. Manufacturers also estimate the useful life of the solar systems to range from 15 to 20 years depending on the type of system used.

With any investment project a company invests a given fraction of the capital cost and finances the remainder. In this study an arbitrary value of $70 \%$ financing was selected for a period of 10 years at the current market interest rate of $17 \%$.

Predicting a single value that will represent the operating and maintenance escalation rate over the next 20 years is difficult, to say the least. Therefore, a range of values was chosen and a sensitivity analysis performed (Chapter 4). Based on current estimates a baseline value of $12.2 \%$ was chosen. 5

Numerous forecasts of fuel price projections exist. Real rates of fuel escalation consistent with Data Resources, Inc. (DRI) projections were used. DRI projects different average annual rates for 1980-1990 and 1990-2000.6

\subsection{Financial As sumptions}

The financial parameters are those whose values are dictated by government institutions (Table II). The most difficult to quantify in any economic study is the discount rate. Economists have devoted many man-years to investigating the discounting issue. A corporate discount rate is often defined as the rate used to evaluate potential investment projects. A guideline often used is the opportunity cost of forgone projects. In 1980 the average return on investment projects for the Fortune "500" companies was approximately $14 \%$, the value chosen for the discount rate in this study.7 Sensitivity analysis to ascertain the effect on the net present value of changes in the discount rate was performed.

The depreciation schedule described in the Economic Recovery Tax Act of 1981 was used.8 This accelerated schedule classifies investments made after December 31, 1980 into one of four categories: three years for vehicles and research and development equipment; five years for business equipment including insulation, new energy-efficient equipment, and energy management systems; and ten or fifteen years for certain types of public utility equipment. 
It is our interpretation ${ }^{9}$ that industrial process heat falls in the five-year category. Thus, investments in an IPH system made after December 31, 1980 and before January 1, 1985 use the following depreciation schedule.

$\begin{array}{cr}\text { Year } & \text { Depreciation } \\ 1 & 15 \% \\ 2 & 22 \% \\ 3-5 & 21 \%\end{array}$

Finally, the appropriate federal and state corporate income tax rates and credits were used where applicable and appear in Table II. 
TABLE II

Financial Parameters

Parameter (Dimensions)

Baseline Varue

Federal Tax Credit (\%)

25

- Investment Tax Credit 10

- Energy Tax Credit

15

Federal Corporate Income Tax Rate

(\%)

46

State Tax Credit

(\%)

- Georgia

0

- North Carolina

$20 \%$ or $\$ 8,000 \max$

- Texas

0

State Corporate Income Tax Rate

(\%)

- Georgia

6

- North Carolina

. 6

- Texas.

0

Depreciation Method*

- Ist Year (\% of Installed Cost) 15

- 2nd Year 22

- 3rd - 5th Years 21

Depreciation Period (Years) 5

Di scount Rate (\%) 14

* Economic Recovery Tax Act of 1981, Public Law 97-34. 


\subsection{CASE STUDIES}

Seven case studies are outlined in this section. In each study it is assumed construction begins in 1981, operation in 1982. A detailed explanation of the net cash flows for years 1 to 5 and for subsequent five-year periods up to year 20 is given for Case Study I, System I: Cash flow tables for all other case studies appear in Appendix $B$.

\subsection{Case Study I}

This report presents the findings from a case study conducted for a food processing plant in Georgia. The potential application for a solar energy system is in heating water, which is used to maintain the temperature of $300,0001 b_{m}$ of hard oil contained in six storage tanks. $0 i l$ within the tanks is maintained between $114^{\circ} \mathrm{F}$ and $120^{\circ} \mathrm{F}$. In sizing a solar energy system for this process, two cases were examined. In one case the systen was sized to provide a maximum oil temperature of $115^{\circ} \mathrm{F}$ while in the other cases a maximum oil temperature of $124^{\circ} \mathrm{F}$ was provided, representing 22 percent and 42 percent of the process heat load respectively. Natural gas will supplement the solar energy system to meet process requirements. The proposed system is a roof-mounted array of flat plate collectors used to heat a propylene glycol solution that flows through the collector loop. A flat plate collector system was selected because of the low temperatures required.

In order to evaluate the economic feasibility of the system described several assumptions have been made and are explained in the previous section. In addition there are several assumptions unique to this case study:

\section{System I System II}

Initial system cost (\$35/ft $\left.\mathrm{ft}^{2}, 1981 \$\right)$

collector array size $\left(\mathrm{ft}^{2}\right)$

Annual energy savings $\left(10^{6}\right.$ Btu)

Price of natural gas in 1982 (1982 $\left.\$ / 10^{6} \mathrm{Btu}\right)$

Operating life (years)

State of Georgia tax rate (\%)

State of Georgia tax credit (\%)

24,500
700
195.5
5.5
20
6
0

70,000
2,000
580.1
5.51
20
6
0

Based on these assumptions the net cash flows for system I for years 1 to 5 and for subsequent five-year periods up to year 20 were calculated and appear in Table III. Year 0 is the year of installation. The only cash outflow in this year is for equipment and installation cost, $\$ 24,500$. Cash inflow includes the loan proceeds for $70 \%$ of the initial investment, $\$ 17,200$, 
TABLE II I

Net Cash Flow For Case Study I, System I

(Thousands of Current Year Dollars)

1

2

34

45

$6-10 \quad 11-15 \quad 16-20$

Fuel Savings

$\begin{array}{llllllll}1.1 & 1.3 & 1.5 & 1.8 & 2.2 & 19.2 & 35.2 & 76.2\end{array}$

Deductible Expenses:

O\&M

Interest Pmt.

Depreciation

$\begin{array}{rrrrrrrr}.5 & .5 & .6 & .7 & .8 & 5.6 & 9.9 & 17.6 \\ 2.9 & 2.7 & 2.6 & 2.4 & 2.2 & 5.9 & 0.0 & 0.0 \\ 3.7 & 5.4 & 5.1 & 5.1 & 5.1 & 0.0 & 0.0 & 0.0\end{array}$

Taxable Income:

$\begin{array}{llllllll}-5.9 & -7.4 & -6.8 & -6.4 & -5.9 & 7.8 & 25.3 & 58.6\end{array}$

Incame Taxes Payable:

State

Federal

Loan Principal

Net Cash Flow**

\begin{tabular}{|c|c|c|c|c|c|c|c|}
\hline 1.1 & 1.3 & 1.5 & 1.8 & 2.2 & 19.2 & 35.2 & 76.2 \\
\hline $\begin{array}{r}.5 \\
2.9 \\
3.7\end{array}$ & $\begin{array}{r}.5 \\
2.7 \\
5.4\end{array}$ & $\begin{array}{r}.6 \\
2.6 \\
5.1\end{array}$ & $\begin{array}{r}.7 \\
2.4 \\
5.1\end{array}$ & $\begin{array}{r}.8 \\
2.2 \\
5.1\end{array}$ & $\begin{array}{l}5.6 \\
5.9 \\
0.0\end{array}$ & $\begin{array}{l}9.9 \\
0.0 \\
0.0\end{array}$ & $\begin{array}{r}17.6 \\
0.0 \\
0.0\end{array}$ \\
\hline-5.9 & -7.4 & -6.8 & -6.4 & -5.9 & 7.8 & 25.3 & 58.6 \\
\hline $\begin{array}{r}-. .4 \\
-2.6\end{array}$ & $\begin{array}{r}-.4 \\
-3.2\end{array}$ & $\begin{array}{r}-.4 \\
-2.9\end{array}$ & $\begin{array}{r}-.4 \\
-2.8\end{array}$ & $\begin{array}{r}-.4 \\
-2.6\end{array}$ & $\begin{array}{r}.5 \\
3.4\end{array}$ & $\begin{array}{r}1.5 \\
10.9\end{array}$ & $\begin{array}{r}3.5 \\
25.3\end{array}$ \\
\hline .7 & .8 & 1.0 & 1.2 & 1.4 & 12.0 & 0.0 & 0.0 \\
\hline-.1 & .8 & .7 & .7 & .7 & -8.0 & 12.8 & 29.7 \\
\hline
\end{tabular}

* Equipment Cost - Loan Proceeds - Tax Credits $=(24.5-17.2-6.1)=1.2$

** Depreciation is a tax accounting procedure and not an actual expense; therefore, net cash flow equals fuel savings less 0 \& $M$ expense, taxes, and loan service. 
as well as the $25 \%$ federal tax credit, $\$ 6,100$. This comprises the $15 \%$ renewable energy investment tax credit and the standard 10\% tax credit. Thus in year 0 there is a negative cash flow of $\$ 1,200$.

Taxable income is determined by subtracting annual operating expenses from the fuel savings derived from the solar system. These expenses include operating and maintenance cost, depreciation, and loan interest payments. Thus,

Taxable Income = Fuel Savings - [0 \& $M+$ Depreciation + Interest $]$.

Based on the taxable income, state and federal taxes were computed. In many instances taxable income was negative due to leveraged financing and available tax credits. In these cases, taxes were credited, thus increasing net income. This assumes the company has sufficient income from other operations against which the tax benefits may be applied.

Net cash flow was then determined by subtracting operating expenses, taxes, and the loan service from fuel savings. Thus,

Net Cash Flow $=$ Fuel Savings - [Operating Expenses + Taxes + Loan Service].

For all time periods the method of calculating net cash flow is the same. However, cash inflows and outflows for years subsequent to year 5 were grouped to produced one number representing net cash flow for a five-year period. This is recommended because inaccuracies increase in outyears due to unpredictable fuel prices and operating and maintenance costs. To present yearly cash flows in detail may misrepresent the accuracy of the estimates.

After the net cash flow is calculated the net present value, payback period, and internal rate of return can be derived.

Economic Measure

System I Systeni II

Net Present Value (1981\$)

Payback of Initial Investment (Years)

Payback of Total Investment (Years)

Internal Rate of Return (\%)

$\begin{array}{rr}2,700 & 9,200 \\ 2.7 & 2.6 \\ 13 & 12.7 \\ 24 & 26\end{array}$

In both systems under the present conditions and assumptions, retrofitting the existing gas-fired facility with the solar energy system as defined appears to be a favorable investment. A payback period of the initial investment of less than 3 years and an internal rate of return 10-12 percent greater than the discount rate are good indicators of the economic feasibility of the se systems. 


\subsection{Case Study II}

This report presents the findings from a case study conducted at a small rug manufacturing facility in Georgia. The potential application for a solar energy system is the heating of water for the batch dyeing operation, whicin requires a temperature of $200^{\circ} \mathrm{F}$. It is recornmended that the solar energy system be designed to operate in series with a waste recovery system to preheat water to $160^{\circ} \mathrm{F}$. An evacuated-tube collector system is recommended, with the array located on vacant land west of the plant as opposed to a roof-mounted array that would require extensive structural modification of the building. It is estimated that the solar system will provide approximately 16 percent of the process heat requirements.

In order to evaluate the economic feasibility of the system described several assumptions have been made and are explained in the previous section. In addition there are several assumptions unique to this case study:

Initial system cost $\left(\$ 45 / \mathrm{ft}^{2}, 1981 \$\right)$

Collector array size $\left(\mathrm{ft}^{2}\right)$

Annual energy savings $\left(10^{6} \mathrm{Btu}\right)$

Price of natural gas in 1982 (1982\$/106 Btu)

Cperating life (years)

State of Georgia tax rate $(\%)$

State of Georgia tax credit $(\%)$

543,915
12,087
1,500
5.51
20
6
0

Based on these assumptions the net cash flows for the system were calculated as described in Case Study I and appear in Appendix B. Sumary values of economic worth appear below.

Economic Measure

Value

Net Present Value (1981 \$)

Payback of Initial Investment (Years)

Payback of Tulal Irivéslmënl (Years)

$-124,300$

Never

Never

A net present value of $-\$ 124,300$ and cash inflows over the life of the system that never exceed the initial cash outlay clearly suggest under the present conditions and assumptions retrofitting the existing gas-fired facility with the solar energy system as defined is not a favorable investment.

In Section 4.3, alternate values of several parameters will be considered to illustrate that under different conditions and assumptions (some quite realistic) the results may change dramatically. 


\subsection{Case Study III}

This report presents the findings from a case study conducted at a cookie manufacturing facility in Georgia. The potential application for a solar energy system is the preheating of air supplied to the burners of three continuous ovens. In the cookie manufacturing process, temperatures range between $350^{\circ} \mathrm{F}$ and $400^{\circ} \mathrm{F}$. The recommended solar system employs a roof-mounted array of evacuated-tube collectors, which are estimated to provide approximately 8 percent of the process heat requiremients. Evacuated-tube, air-heating collectors were chosen over series-connected, flat plate collectors because they exhibit higher efficiencies at higher output temperatures.

In order to evaluate the economic feasibility of the system described several assumptions have been made and are explained in the previous section. In addition there are several assumptions unique to this case study:

Initial system cost $\left(\$ 45 / \mathrm{ft}^{2}, 1981 \$\right)$

Collector array size $\left(\mathrm{ft}^{2}\right)$

Annual energy savings $\left(10^{6} \mathrm{Btu}\right)$

Price of natural gas in $1982\left(1982 \$ / 10^{6}\right.$ Btu)

Operating life (years)

State of Georgia tax rate (\%)

State of Georgia tax credit (\%)

339,300
7,540
923
5.51
20
6
0

Based on these assumptions, the net cash flows for the system were calculated as described in Case Study I and appear in Appendix B. Summary values of economic worth appear below.

Economic Measure

Value

Net Present Value (1981 \$)

Payback of Initial Investment (Years)

$-78,400$

Never

Payback of Total Investment (Years)

Never

A net present value of $-\$ 78,400$ and cash inflows over the life of the system that never exceed the initial cash outlay clearly suggest under the present conditions and assumptions retrofitting the existing gas-fired facility with the solar energy system as defined is not a favorable investment. 


\subsection{Case Study IV}

This report presents the findings from a case study conducted in a textile plant in North Carolina. The potential application for a solar energy system is in heating water for boiler make-up and wetting tank processes. In both processes the end-use temperature is $120^{\circ} \mathrm{F}$. Because of the low temperature required two types of collector systems were considered: flat plate and shallow solar pond. The shallow solar pond (SSP) system was chosen to be the most attractive investment. In the boiler make-up process an array size of $6,400 \mathrm{ft}^{2}$ was used in the analysis; in the wetting tank process an array of $12,800 \mathrm{ft}^{2}$ was used. It is estimated the proposed systems will provide approximately 15 percent and 7 percent respectively of the process heat requirements.

In order to evaluate the economic feasibility of the SSP systems described several assumptions have been made and are explained in the previous section. In addition there are several assumptions unique to this case study:

\begin{tabular}{lcc}
\hline & System I & System II \\
\hline Initial system cost $\left(\$ 20 / \mathrm{ft}^{2}, 1981 \$\right)$ & 128,000 & 256,000 \\
Collector array size ( $\left.\mathrm{ft}^{2}\right)$ & 6,400 & 12,800 \\
Annual energy savings $\left(10^{6} \mathrm{Btu}\right)$ & 730 & 1,463 \\
Cost of \#6 fuel oif in $1982\left(1982 \$ / 10^{6} \mathrm{Btu}\right)$ & 7.36 & 7.36 \\
Operating life (years) & 15 & 6 \\
State of N.C. tax rate (\%) & 6 & 8,000 \\
State of N.C. tax credit $(\$)$ & 8,000 & \\
\hline
\end{tabular}

Based on these assumptions, the net cash flows for the systems were calculated as described in Case Study I and appear in Appendix B. The net present value and payback periods were then derived. 
The payback of the initial investment for System I occurs in the installation year. Equipment cost of $\$ 128,000$ is offset by $\$ 89,600$ loan proceeds and $\$ 40,100$ in tax credits. Thus, a cash inflow of $\$ 1,700$ exists in year zero. The net present value of $-\$ 500$, however, indicates that thie discounted costs over the 15-year period slightly outweigh the discounted benefits.

In System II as well as in system I the economic indicators suggest different conclusions regarding the relative desirability of the two projects. According to economic theory, it would be advisable to use the net present value criterion to resolve any ambiguities. However, since many companies base their decisions to invest on the payback period of the initial investment, the analyst needs to present both measures to management for evaluation.

\subsection{Case Study V}

This report presents the findings from a case study conducted in a textile plant in North Carolina. The potential application for a solar energy system is found in the boiler make-up process. Natural gas is not available in. this area, therefore, boilers currently use \#6 fuel oil. Because a collector outlet temperature of $200^{\circ} \mathrm{F}$ is desired, an evacuated-tube collector system is proposed, since it is capable of both obtaining the desired outlet temperature and collecting diffuse and direct solar radiation. It is estimated that the proposed system will provide approximately 14 percent of the process heat requirements.

In order to evaluate the economic feasibility of the system described several assumptions have been made and are explained in the previous section. In addition there are several assumptions unique to this case study:

Initial system cost $\left(\$ 45 / \mathrm{ft}^{2}, 1981 \$\right)$

Collector array size $\left(\mathrm{ft}^{2}\right)$

Annual energy savings (106 Btu)

Cost of \#6 fuel oil in $1982\left(1982 \$ / 10^{6} \mathrm{Btu}\right)$

Operating 1 ife (years)

State of N.C. tax rate (\%)

State of N.C. tax credit (\$)

$$
\begin{gathered}
90,000 \\
2,000 \\
530.4 \\
7.36 \\
20 \\
6 \\
8,000
\end{gathered}
$$

Based on these assumptions, the net cash flows for the systems were calculated as described in Case Study I and appear in Appendix B. Sunmary values of economic worth appear at top of next page. 
In year zero, the installation year, equipment cost is $\$ 90,000$. However with $70 \%$ financing, a federal tax credit of $25 \%$, and a state tax credit of $8.9 \%$ a cash inflow of $\$ 3,500$ results. Thus, a payback of the initial investment of less than one year, coupled with a positive net present value of $\$ 10,100$ over the 20-year life indicates the solar energy system as defined to be an extremely attractive investment.

The analysis of the evacuated tube collector system appears to be economically feasible as opposed to the ETC systems of the two prior studies (Case Studies II and III) as a result of the higher cost of fuel displaced and the state tax credit. In the former studies the solar energy system displaced natural gas at a cost of $\$ 5.51 / \mathrm{MMBtu}$ as opposed to \#6 residual oil at a cost of $\$ 7.48 / \mathrm{MMBtu}$ in this system. Also, the state of North Carolina allows an investment tax credit of $20 \%$ up to a maximum of $\$ 8,000$ for production of industrial process heat using a solar energy system, whereas in Georgia no state energy tax credit exists.

\subsection{Case Study VI}

This report presents the findings from a case study conducted at a bean dip processing facility in Texas. The potential application for a solar energy system is in heating water from $60^{\circ} \mathrm{F}$ to $140^{\circ} \mathrm{F}$. Presently boilers supply 15 psig steam to heat exchangers that provide the process heat load of $2.1 \times 10^{9}$ Btu/yr. The proposed system is a roof-mounted array of flat plate collectors. This type of collector was selected because of the low temperature required.

In order to evaluate the economic feasibility of the systems described several assumptions have been made and are explained in the previous section. In addition there are several assumptions unique to this case study:

Initial system cost $\left(\$ 35 / f t^{2}, 1981 \$\right)$

Collector array size $\left(\mathrm{ft}^{2}\right)$

Annual energy savings $\left(10^{6} \mathrm{Btu}\right)$

Cost of natural gas in $1982\left(1982 \$ / 10^{6} \mathrm{Btu}\right)$

Operating life (years)

State of Texas Tax rate $(\%)$

State of Texas Tax credit (\%)

192,500

5,500

1,110

0 
Based on these assumptions, the net cash flows for the system were calculated as described in Case Study $I$ and appear in Appendix B.

Economic Measure

Value

Net Present Value (1981\$)

Payback of Initial Investment (Years)

$-36,000$

Never

Payback of Total Investment (Years)

Never

A net present value of $-\$ 36,000$ and cash inflows over the life of the system that never exceed the initial cash outlay clearly suggest under the present conditions and assumptions, retrofitting the existing gas-fired facility with the solar energy system as defined does not appear to be a favorable investment.

The major reason this flat plate system is not economically feasible as opposed to the systems described in Case Study I is a result of the low cost of natural gas in Texas. In Case Study I natural gas cost $\$ 5.51 / \mathrm{MMBtu}, 49 \%$ above the predicted 1982 price of $\$ 3.69 /$ MMBtu in Texas.

\subsection{Case Study VII}

This report presents the findings from a case study conducted at a sausage casing plant in Texas. The potential application for a solar energy system is to generate steam, which is used for hot water, space heating, and drying at temperatures between $120^{\circ} \mathrm{F}$ and $180^{\circ} \mathrm{F}$. The proposed system is a roof-mounted array of parabolic trough collectors. The collector array will supply steam to the plant's main steam line by means of a flash boiler and is estimated to produce an output of $328 \mathrm{lbs} / \mathrm{hr}$.

In order to evaluate the economic feasibility of the systems described several assumptions have been made and are explained in the previous section. In addition, there are several assumptions unique to this case study:

Initial system cost $\left(\$ 50 / \mathrm{ft}^{2}, 1981 \$\right)$

Collector array size $\left(\mathrm{ft}^{2}\right)$

Annual energy savings (106 Btu)

Cost of natural gas in $1982\left(1982 \$ / 10^{6}\right.$ Btu)

Operating life (years)

State of Texas tax rate $(\%)$

State of Texas tax credit $(\%)$

150,000

3,000

890

\subsection{8}


Based on these assumptions, net cash flows for the system were calculated as described in Case Study. I and appear in Appendix B. Summary values of economic worth appear below.

$\begin{array}{ll}\text { Economic Measure } & \text { Value }\end{array}$

Net Present Value (1981\$)

Payback of Initial Investment (Years)

$-25,900$

Payback of Total Investment (Years)

A net present value of $-\$ 25,900$ and a payback period of 19.5 years clearly suggest that under the present conditions and assumptions, retrofitting the existing gas-fired facility with the solar energy system as defined to generate process steam does not appear to be a good investment.

The low cost of natural gàs in Texas $(\$ 3.78 / \mathrm{MBtu})$ and the high cost of a parabolic trough collector system $\left(\$ 50 / \mathrm{ft}^{2}\right)$ results in a negative net present value and an unfavorable payback period. The economics may reverse if the prediction that the collector cost will drop to $\$ 20 / \mathrm{ft}^{2}$ by 1983 is realized or a location in a state with a higher cost of natural gas is selected (See Section 4.3).

\subsection{Summary}

A summary of the nine proposed systems appears in Table IV. Case Study I, a flat plate collector system in Georgia; Case Study IV, a shallow solar pond system in North Carolina; and Case Study V, an evacuated tube system in North Carolina; appear financially desirable by one or more economic measures.

\subsection{Levelized Cost of Energy Comparison}

Each year over the system's life the cost of energy will likely increase. This increasing series of costs can be reduced to an equivalent equal-cost series known as the levelized or annualized cost as described in Section 2.0.

Figure 1 illustrates the levelized costs for the four generic case studies. For each system the levelized cost of natural gas (or \#6 fuel oil) is compared to the levelized cost of the combined solar-fossil system. The latter can be viewed as a weighted average of the levelized cost of the solar system and the levelized cost of the fossil system per unit of energy supplied by each.

In the case of the flat plate collector system in Georgia, defined in Case Study I, System I, 22 percent of the energy load can be met with the solar system defined having a levelized cost of $\$ 19.60 / \mathrm{MMBtu}$; natural gas supplies the remaining 78 percent with a levelized cost of $\$ 21.68 / M M B t u$. Thus, the levelized cost of the combined solar-fossil system is $\$ 21.22 / \mathrm{MMBtu}, \$ .46 / \mathrm{MMBtu}$ less than the present natural gas system. 
TABLE IV

Summary of Case Studies

\begin{tabular}{lccc}
\hline Case Study & $\begin{array}{c}\text { Present Value } \\
(1981 \$)\end{array}$ & $\begin{array}{c}\text { Payback of } \\
\text { Initial Investment } \\
\text { (Years) }\end{array}$ & $\begin{array}{c}\text { Payback of } \\
\text { Total Investment } \\
\text { (Years) }\end{array}$ \\
\hline I, System I & 2,700 & 2.7 & 13 \\
I, System II & 9,200 & 2.6 & 12.7 \\
II & $-124,300$ & Never & Never \\
III & $-78,400$ & Never & Never \\
IV, System I & -500 & 0 & 14.3 \\
IV, System II & $-9,000$ & 1.7 & 14.5 \\
V & 10,100 & 0 & 13.7 \\
VI & $-36,000$ & Never & Never \\
VII & $-25,900$ & 19.5 & 19.5 \\
\hline
\end{tabular}




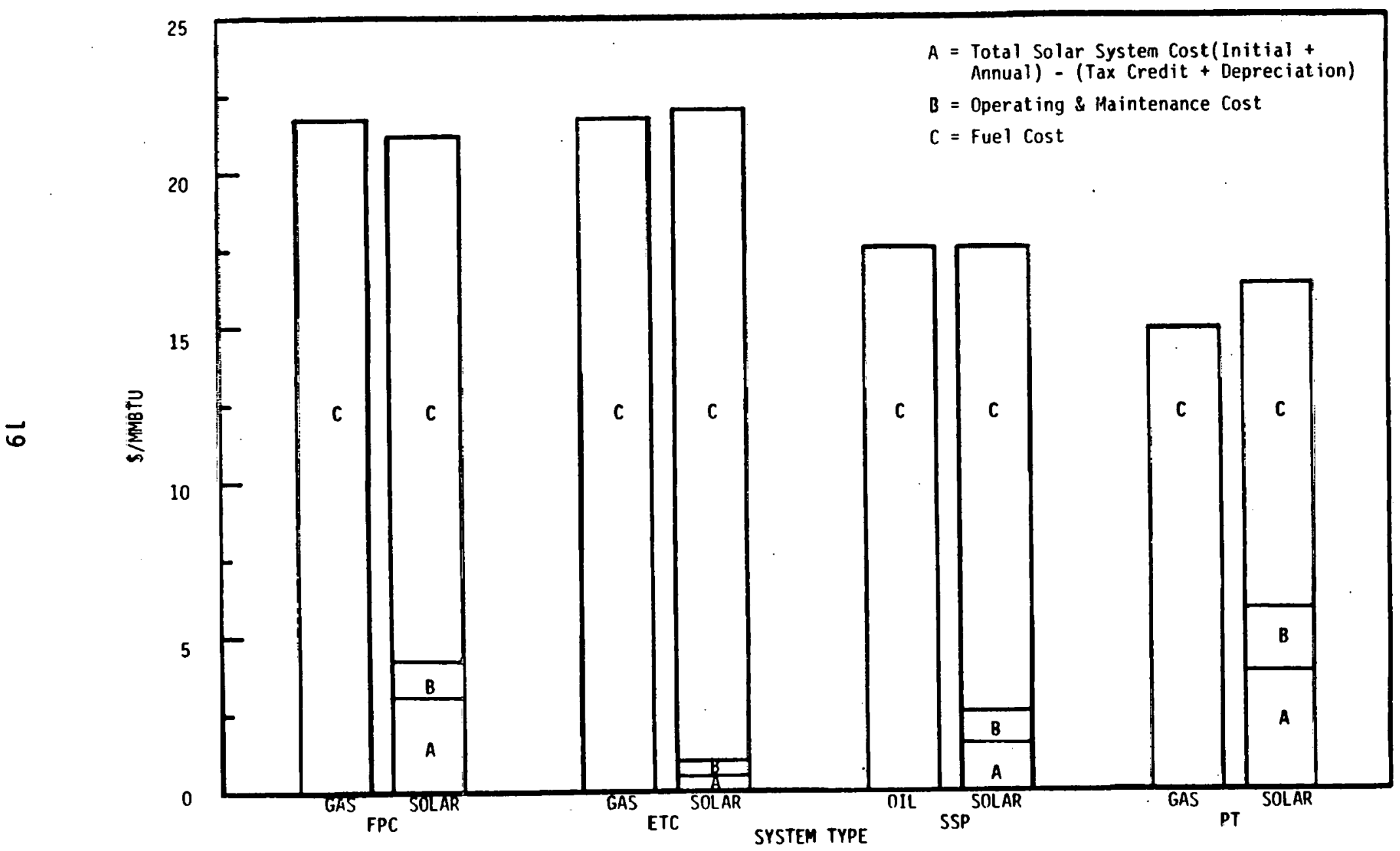

Figure 1. Levelized Cost of Energy 
The evacuated tube collector system in Georgia, defined in Case Study II, has a levelized cost of $\$ 34.19 / \mathrm{MMBtu}$; this is approximately $55-60 \%$ more expensive than the levelized cost of natural gas $(\$ 21.68 / \mathrm{MMBtu})$. However, the cambined system has a levelized cost of only \$21.97/MMBtu, since the solar system is designed to meet oniy 2.3 percent of the annual energy load.

The shallow solar pond system in North Carolina, defined in Case Study IV, System I, supplies approximately 15 percent of the energy load with a levelized cost of $\$ 17.63 / \mathrm{MMBtu}$. The combined solar-fossil system has a levelized cost of $\$ 17.53 / \mathrm{MMBtu}$, just $\$ .02 / \mathrm{MMBtu}$ more than the present $\# 6$ fue 1 0 il system (\$17.51/MMBtu).

Lastly, the parabolic trough system in Texas was designed to meet 33 percent of the annual energy load. The levelized cost of the combined solar-fossil system is $\$ 16.30 / \mathrm{MMBtu}$, a weighted average of $\$ 14.87 / \mathrm{MMBtu}$ and $\$ 19.27 / \mathrm{MMBtu}$ the levelized cost of the natural gas and solar systems respectively.

In summary, of the four case studies analyzed the solar-fossil system that is economically desirable utilizes a flat plate collector system with a natural gas back-up in Georgia. 


\subsection{SENSITIVITY ANALYSIS}

In the previous section nine case studies were analyzed to determine their economic feasibility. These studies represent four collector systems: flat plate, evacuated tube, parabolic trough, and shallow solar pond.

In this section a fuel price projection analysis, illustrating the price natural gas or \#6 fuel oil needs to reach before the net present value of the solar system equals zero, will be discussed. The effect on the net present value and capital payback period of changes in the depreciation schedule as outlined in the Economic Recovery Tax Act of 1981 will be illustrated. Lastly, a sensitivity analysis illustrating the responsiveness of the dependent variable, net present value, to changes in some of the independent variables: discount rate, fuel escalation rate, tax credit, collector cost, and inflation rate will be discussed.

\subsection{Fuel Price Projection Analysis}

4.1.1 Flat Plate Collector System, Case Study I, System I. As discussed in the previous section, augmenting an existing natural gas system with the solar energy system defined yields a NPV of $\$ 2,700$, an IRR of $24 \%$, and a payback of the initial investment in 2.7 years. Thus, a flat plate collector system in Georgia would be a favorable investment today, and a breakeven analysis is not necessary.

4.1.2 Evacuated Tube System, Case Study II. Three natural gas price forecasts are illustrated in Figure 2. These represent two of the most widely quoted forecasting groups: Chase Econometrics and Data Resources, Inc. (DRI). The Chase forecast is a ten-year annual forecast 10; DRI's is a twenty-year forecast with a constant real escalation rate for years 1980 1990 and 1990 - 2000.11 This real escalation rate was added to a forecasted 12 percent nominal inflation rate. The third forecast is currently used by SERI's Solar Thermal Program Branch and is in five-year increments. 12

This case study is in Georgia, where natural gas cost \$3.50/MMBtu in 1980. To this price was added a 27 percent increase that occurred between May 1980 and May $1981^{13}$ and a 24 percent predicted increase from 1981 to 1982.14 The resulting price of $\$ 5.51 / \mathrm{MMBtu}$ in 1982 is used as the starting point for the SERI and DRI forecasts. The chase forecast is applied to the 1981 price of $\$ 4.45 / M M B t u$ since it is in annual increments.

The evacuated tube system defined will have a net present value of zero when the price of natural gas increases from the predicted 1982 price of $\$ 5.51 / M M B t u$ to $\$ 17.14 / M M B t u$. In this analysis values of all parameters except fuel cost were held constant at their 1981 values. The step function that occurs in 1985 illustrates the effect of the energy tax credit expiring in that year. While the tax credit is still in effect the breakeven point occurs when natural gas reaches a price of $\$ 12.61$, without the tax credit the price of natural gas must increase to $\$ 17.14 / \mathrm{MMBtu}$. According to Chase's forecast, this price will be reached after 1990; DRI's forecast predicts 1988, and SERI's 1989. 


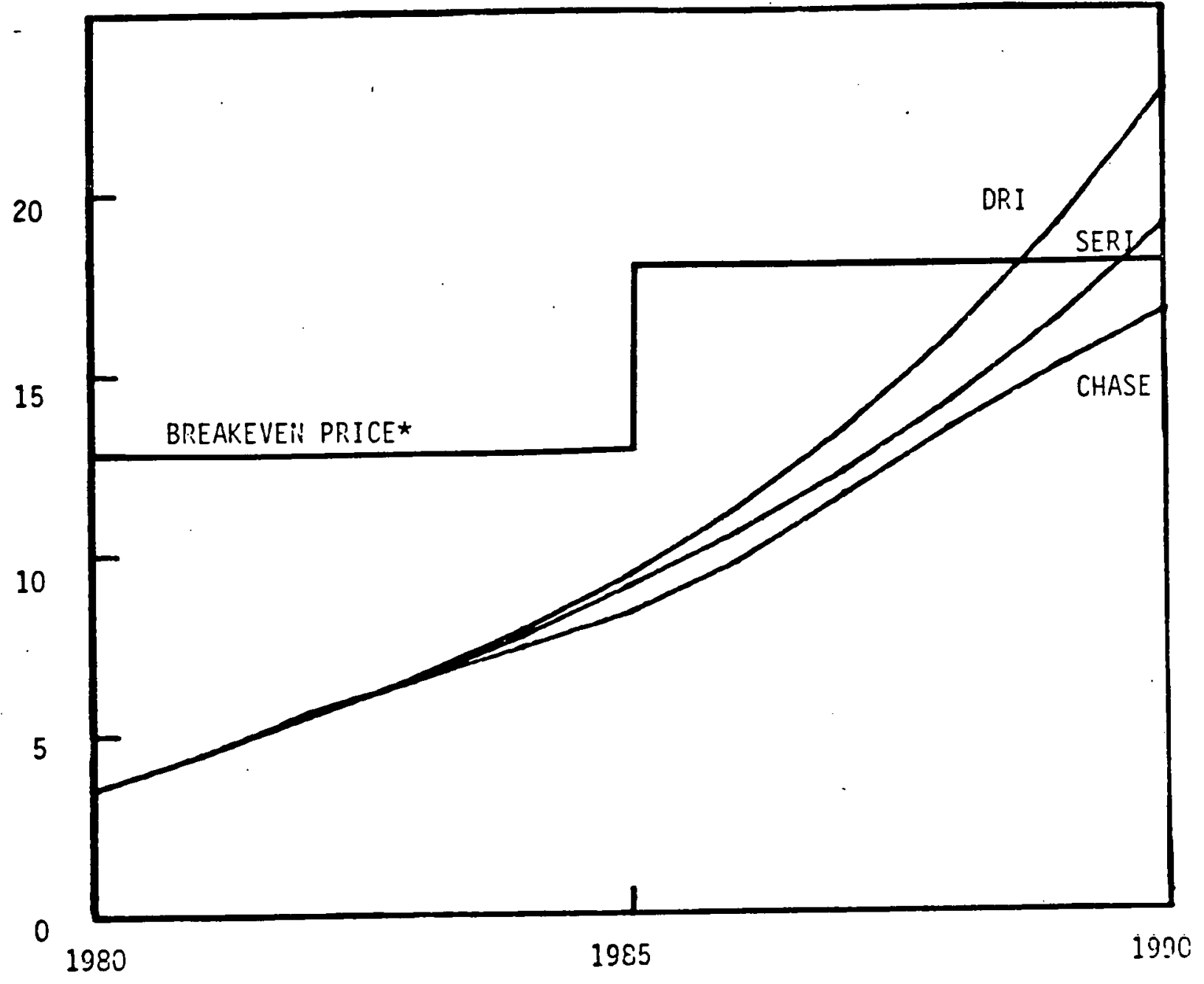

Figure 2

Breakeven Analys is Versus

Natural Gas Price Forecasts - Georgia

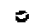

* Price of natural gas at which sular IPH (evacuated tube) system results in a NPV of zero. 
4.1.3 Shallow Solar Pond System, Case Study IV, System I. Three residual (\#6) oil price forecasts are illustrated in Figure 3 . The data were obtained from the same forecasting groups as in the previous study. The price for \#6 fuel oil in 1981 was $\$ 6.24 /$ MMBtu. 15 Energy User's News 16 predicted a 20 percent price increase in 1982 in the South. This predicted 1982 price of $\$ 7.49 / \mathrm{MMBtu}$ was used as the starting point for all three forecasts.

The shallow solar pond system defined, with the values of all parameters except fuel cost held constant at their 1981 values, will have a net present value of zero when \#6 fuel oil increases from $\$ 7.49 / \mathrm{MMBtu}$ ( $\$ 1.12 /$ gallon) to $\$ 7.59 /$ MMBtu ( $\$ 1.35 /$ gallon). This minute increase will probably occur within the year. Thus, a shallow solar pond system as defined in North Carolina should be seriously considered today.

4.1.4 Parabolic Trough System, Case Study VII. The same escalation rates as found in Case study II are used in this study. However, this study represents a sausage casing plant in Texas which paid $\$ 2.40 / \mathrm{MMBtu}$ for natural gas in 1980. Thus, the 27 percent increase that occurred between May 1980 and May 1981 was applied to the $\$ 2.40 / \mathrm{MMBtu}$ instead of the $\$ 3.50 / \mathrm{MR}: \mathrm{Btu}$ as in Case Study II (Figure 4).

The parabolic trough system defined, with the values of all parameters except fuel cost held constant at these 1981 values, will have a net present value of zero when the price of natural gas increases from the predicted 1982 price of $\$ 3.78 / \mathrm{MMBtu}$ to $\$ 8.12 / \mathrm{MMBtu}$. The step function that occurs in 1985 illustrates the effect of the energy tax credit expiring in that year. While the tax credit is still in effect, the breakeven point occurs when natural gas reaches a price of $\$ 6.10 / \mathrm{MMBtu}$; without the tax credit the price of natural gas must increase to $\$ 8.12$ MMBtu. This will occur in 1986 according to DRI's and SERI's forecast and 1987 using Chase's forecast.

\subsection{Effects of 1981 Tax Law}

The Economic Recovery Tax Act of 1981 has changed the depreciation schedule substantially. for IPH systems. Formerly a company used the double-declining balance, sum-of-years-digits, or some other accelerated method of depreciation for the life of the equipment, such as 15 or 20 years. Under the new act, IPH systems placed in service before 1985 can be depreciated in five years with the following schedule: $15 \%$ the first year, $22 \%$ the second, and $21 \%$ the third through fifth years.

Table $V$ shows the effect on the net present value and payback period of these changes in the depreciation schedule. 


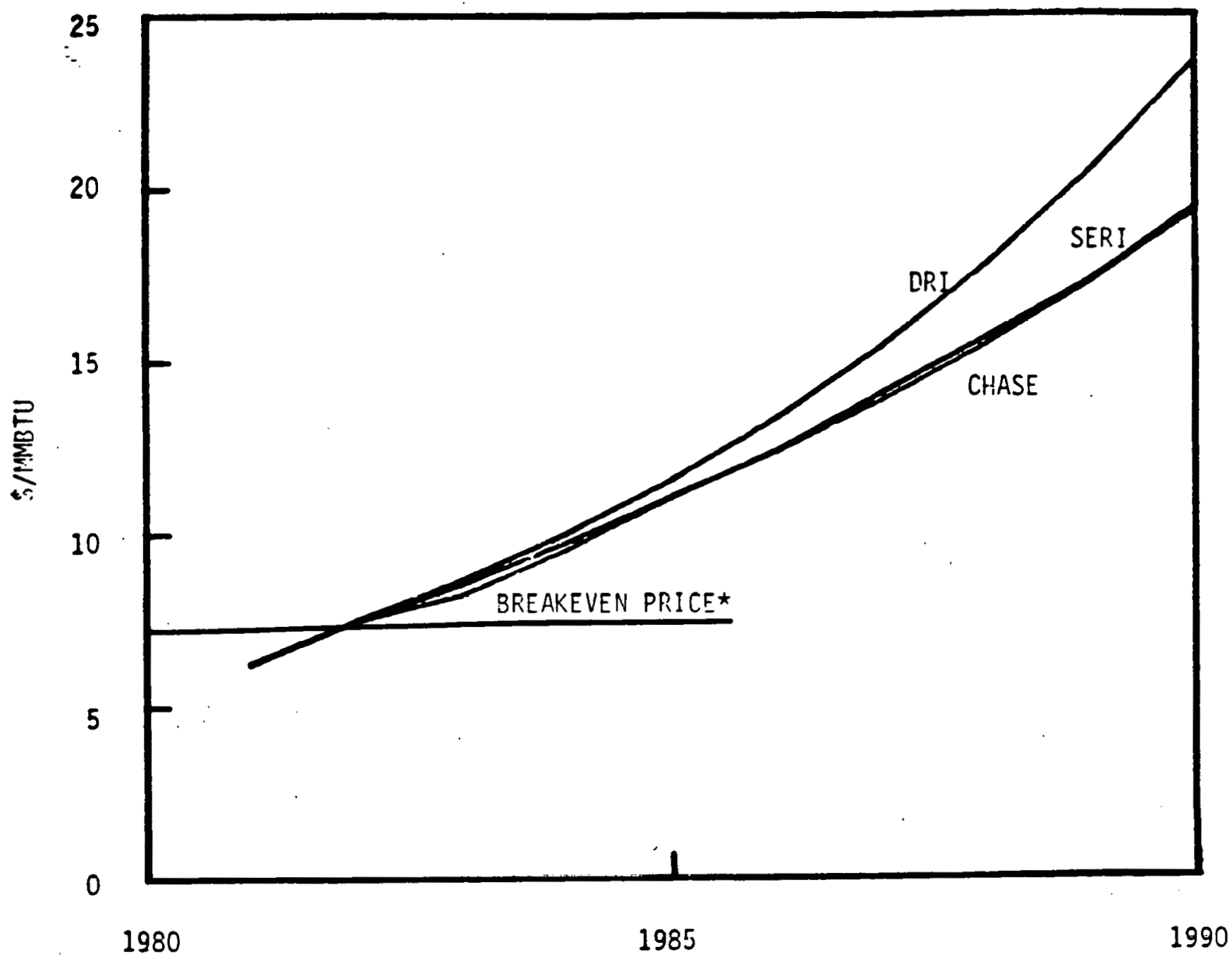

Figure 3

Breakeven Analys is Versus

Residual (\#6) Fuel 0il Price - North Carolina

* Price of \#6 fuel oil at which solar IPH (shallow solar pond) system results in a NPV of zero. 


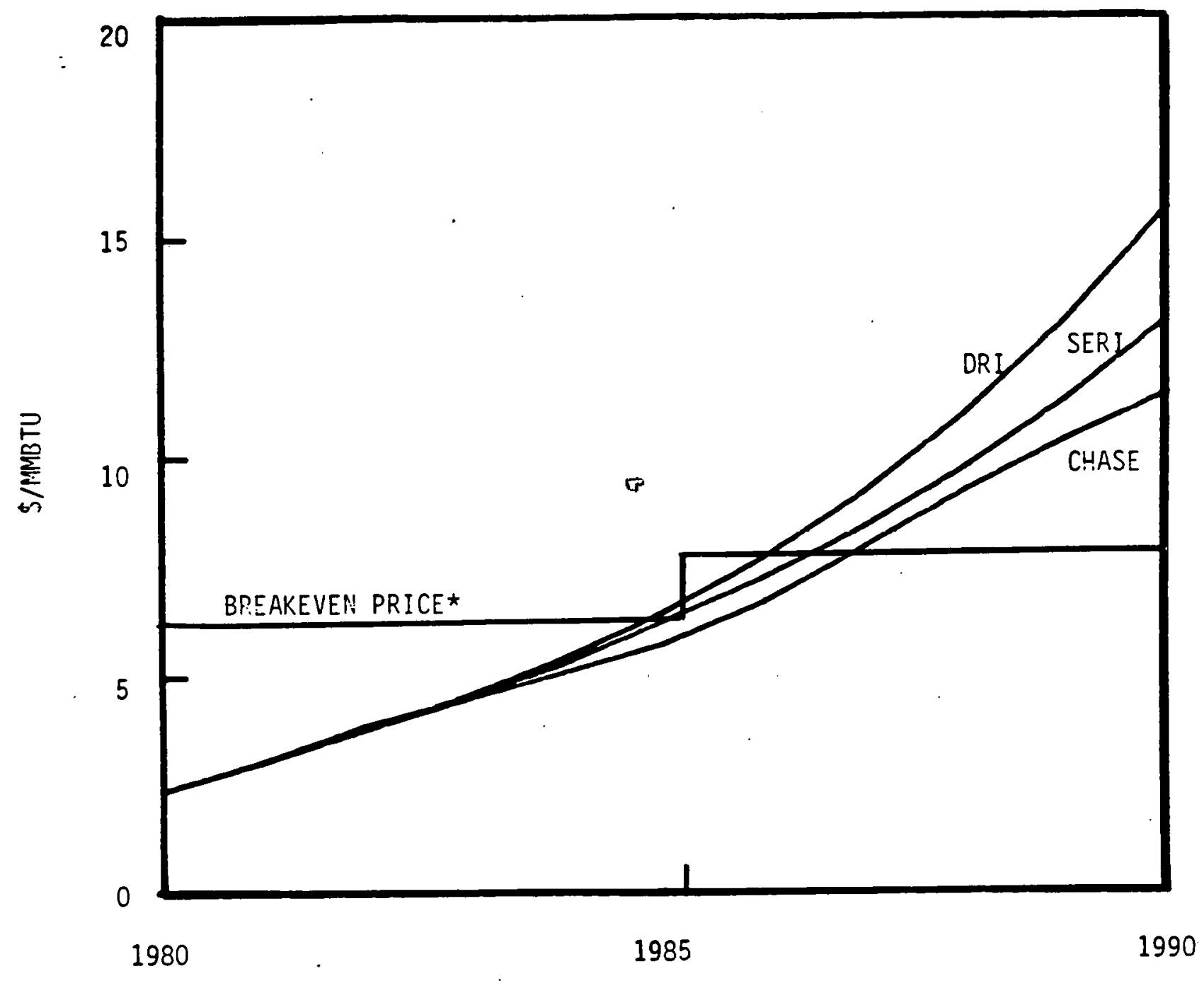

Figure 4

Breakeven Analys is Versus

Natural Gas Price Forecasts - Texas

* Price of natural gas at which solar IPH (parabolic trough) system results in a NPV of zero. 
TABLE V

Depreciation Analysis

Economic Recovery Tax Act

Case Study
Net Present Payback of

Value

(1981\$)
Initial Inv.

(Yrs)
Double Declining Balance

Net Present Payback of Value Initial Inv. (1981\$) (Yrs)

\begin{tabular}{lrcrc}
\hline I, Flat Plate & 2,700 & 2.7 & -300 & 13.9 \\
II, Evacuated & $-124,300$ & Never & $-191,100$ & Never \\
IV, Shallow Solar Pond & -500 & 0 & $-11,400$ & 0 \\
VII, Parabolic Trough & $-32,400$ & Never & $-44,400$ & Never \\
\hline
\end{tabular}

Whether the decision criterion is a positive net present value or a payback of the initial investment in less than five years, the most. significant change occurs in the case of the flat plate system. In this case, a decision not to invest would have been made under the double declining balance method of depreciation. However, under the new depreciation schedule an economically desirable investment exists.

The new tax depreciation schedule improves all systems, as its purpose is to encourage firms to invest in new plants and equipment. This is accomplished by permitting companies to deduct investment costs over fewer years, thereby reducing taxes and increasing cash on hand.

\subsection{Sensitivity of Net Present Value}

This subsection illustrates the responsiveness of the dependent variable, net present value, to changes in the independent variables: collector costs, discount rate, fuel escalation rate, tax credit, and 0 \& $M$ inflation rate.

The responsiveness of the net present value of the flat plate collector system described in Case Study I, System I is illustrated in Figure 5 . It is evident the net present value is most sensitive to changes in the fuel escalation rate and collector costs; for example, a 10 percent decrease in the projected fuel escalation rate results in a 60 percent decrease in net present value. In the case of the collector cost an inverse relationship exists; a ten percent decrease in the collector cost results in approximately a forty percent increase in the net present value.

The responsiveness of the met present value of the evacuated tube system described in Case Study III is illustrated in Figure 6. It is evident the NPV is most sensitive to changes in the collector cost, fuel escalation rate, 


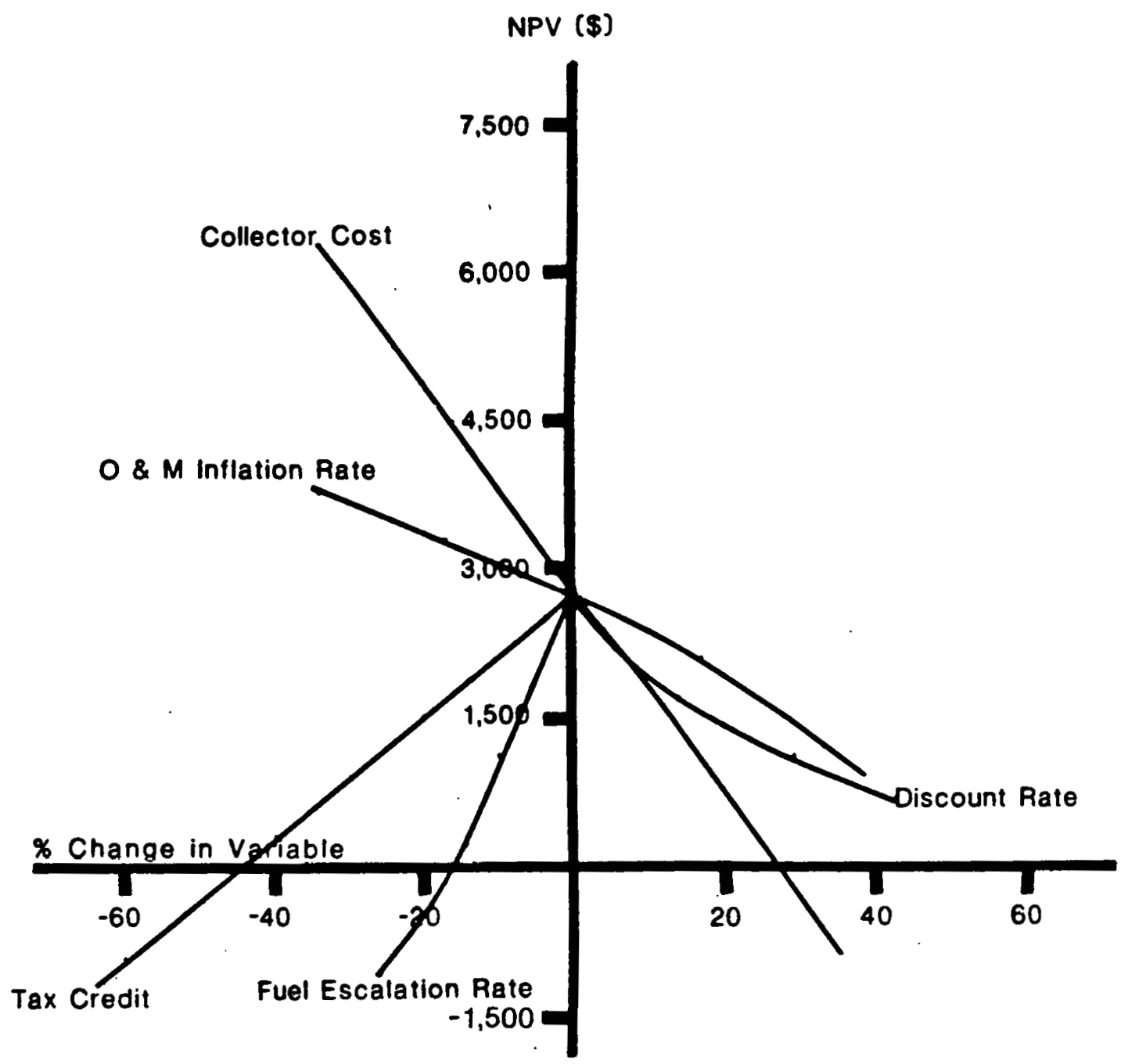

Figure 5. Sensitivity of Net Present Value - Flat Plate System 


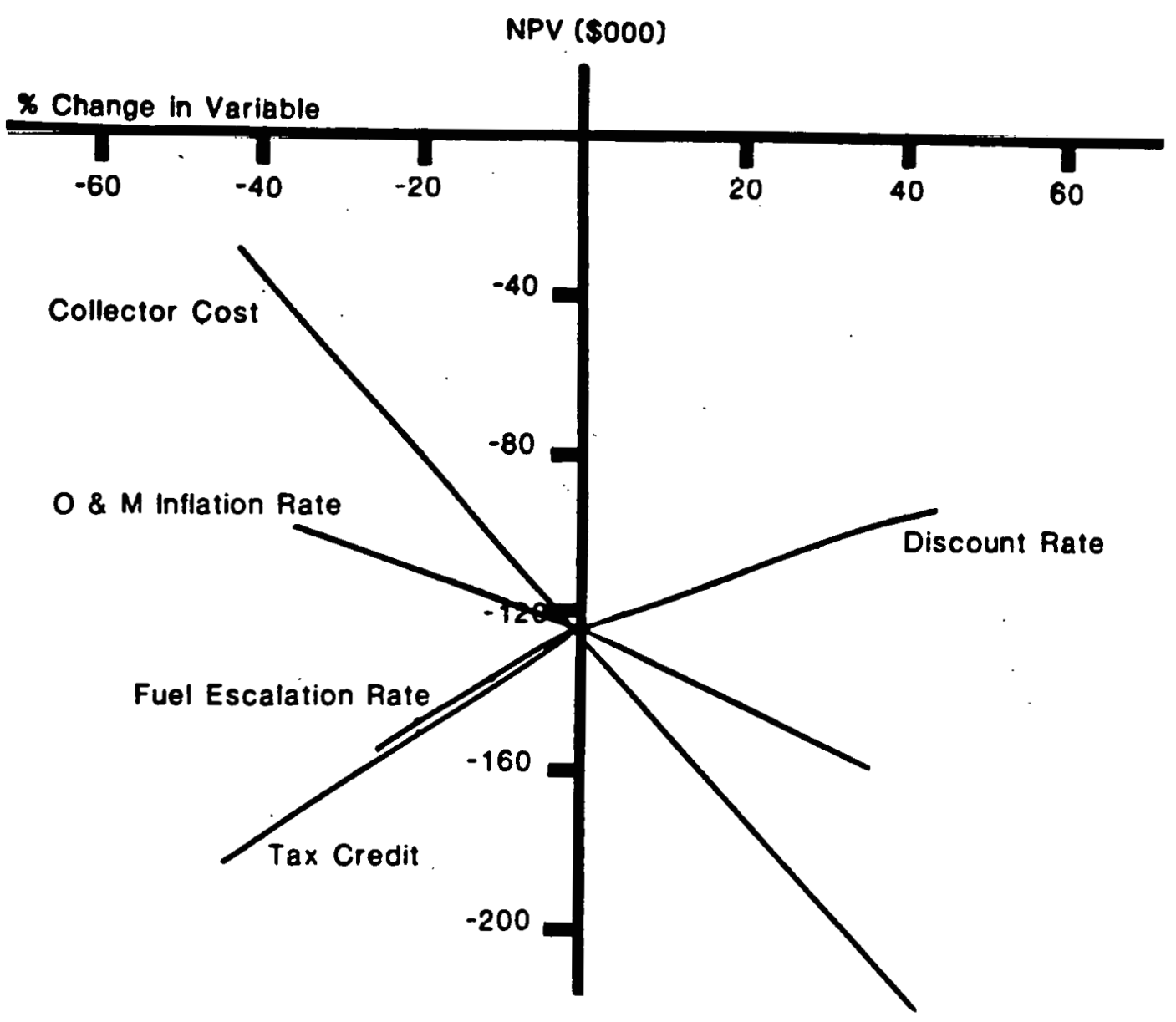

Figure 6. Sensitivity of Net Present Value - Evacuated Tube System 
and tax credit. A 22 percent decrease in the collector cost results in a 40 percent increase in the NPV $(\$ 49,300)$. In the case of the fuel escalation rate and tax credit, a direct relationship exists with the net present value; i.e., as the projected fuel escalation rate and/or tax credit allowances decrease, the NPV also decreases. In this case study, the economic feasibility of the system is so undesirable that a major change in more than one variable is needed for the solar system as defined to be a favorable investment.

The responsiveness of the net present value of the shallow solar pond system described in Case Study IV, System I is illustrated in Figure 7. Similar to the former case studies illustrated in Figure 5 and 6 , the net present value is most sensitive to changes in the collector cost, tax credit, and fuel escalation rate. In the case of the fuel escalation rate and tax credit a direct relationship exists with the net present value; for example, a 20 percent decrease in the tax credit from the current 25 percent (investment plus energy tax credit) to 20 percent results in a decrease in the NPV from $-\$ 500$ to $-\$ 6,850$. On the other hand, a 25 percent decrease in the collector cost from the current $\$ 20 / \mathrm{ft}^{2}$ to $\$ 15 / \mathrm{ft}^{2}$ results in an increase of $\$ 11,900$ in the net present value. The NPV of the collector system defined in this case study is almost at the breakeven point, i.e., where the discounted benefits equal the discounted costs. Thus these three parameters should be closely watched, as a small percent change in any one could result in a positive net present value.

The responsiveness of the NPV of the parabolic trough system described in Case Study VII is illustrated in Figure 8. It is evident the NPV is most sensitive to changes in the collector cost. However, similar to Case Study III, Figure 6, the economic feasibility of the system is so undesirable that a major change in more than one variable is needed for the solar system as defined to be a favorable investment. 


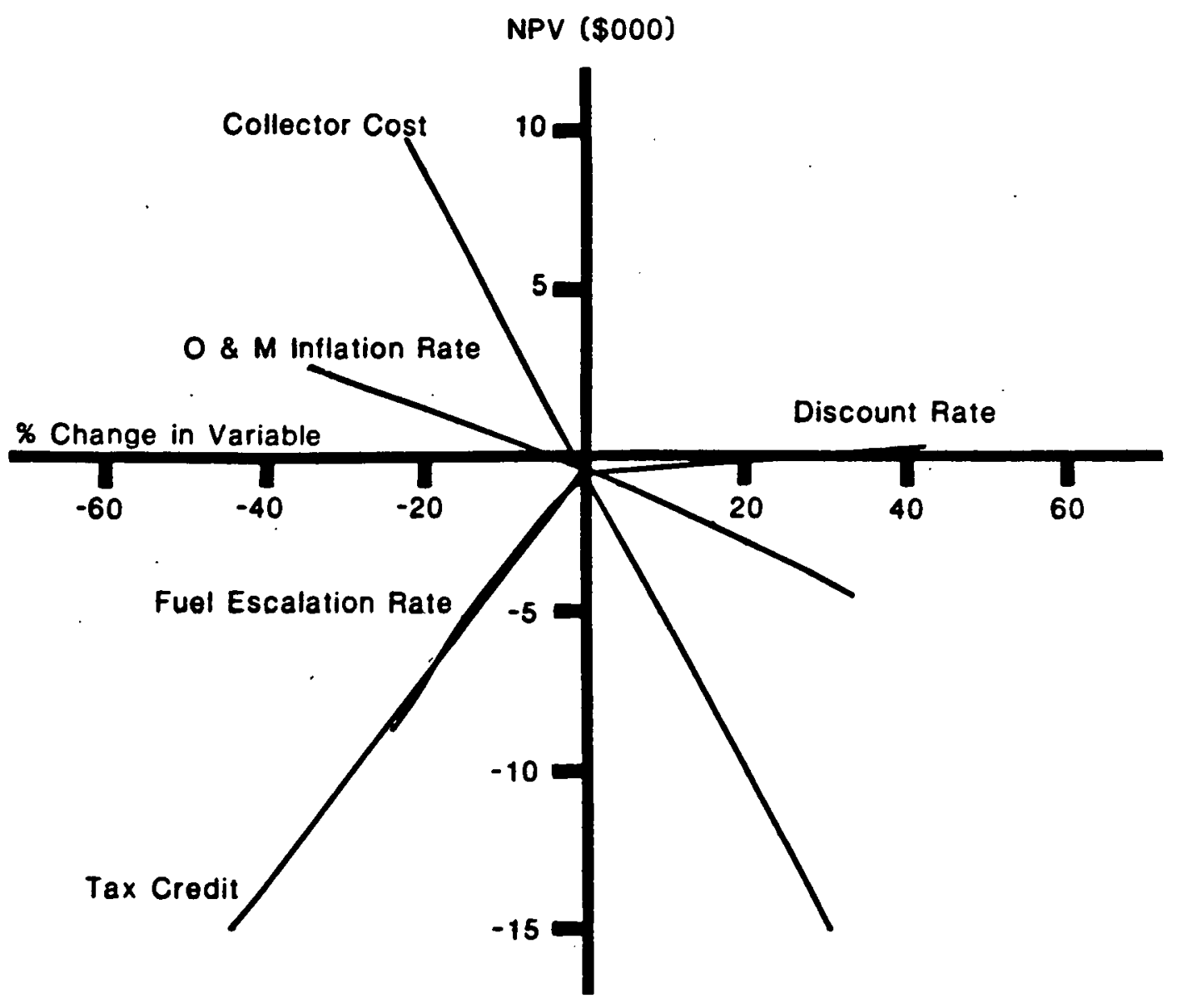

Figure 7. Sensitivity of Net Present Value - Shallow Solar Pond System 


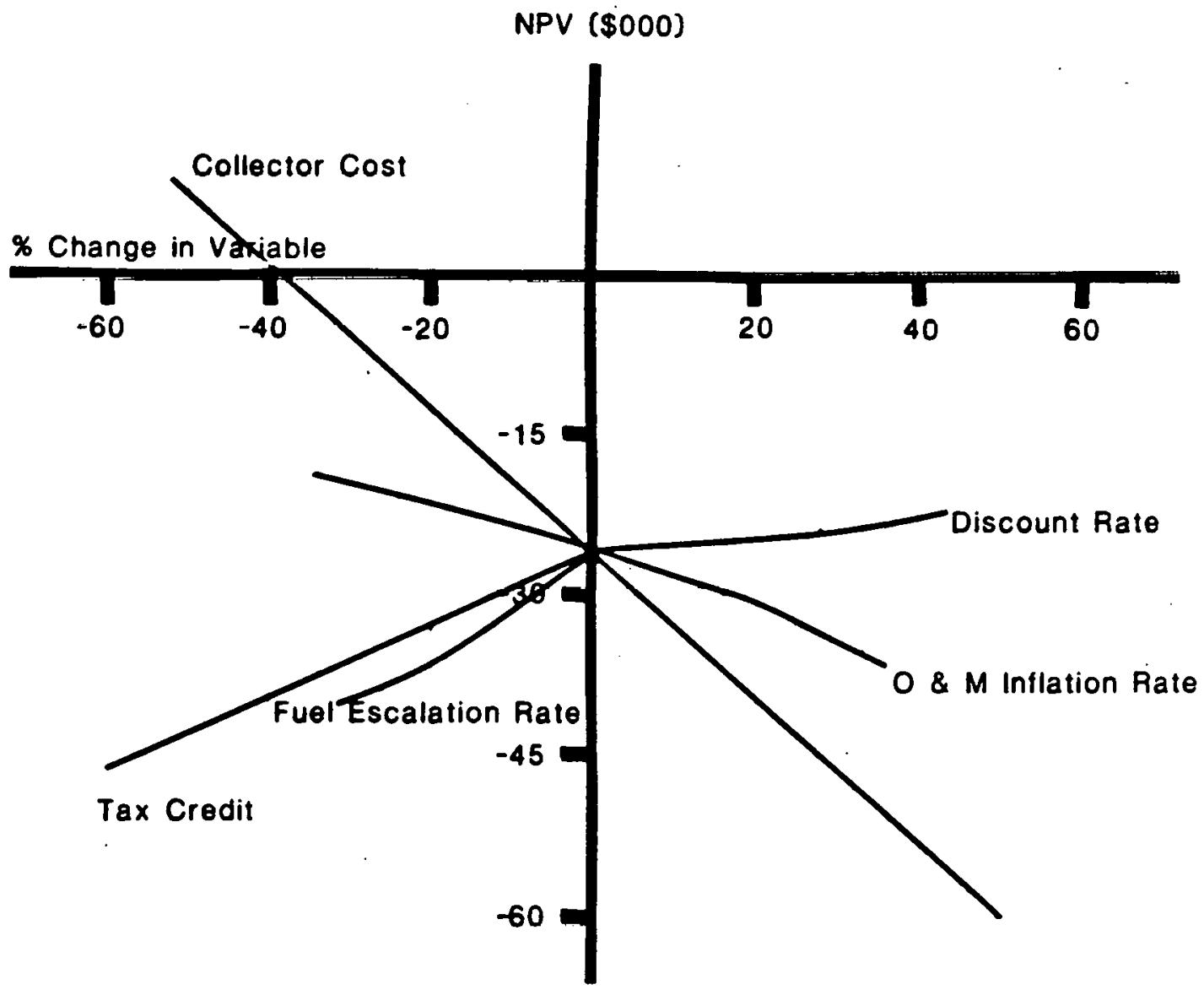

Figure 8. Sensitivity of Net Present Value - Parabolic Trough System 


\subsection{CONCLUSIONS}

Nine case studies representing the food processing and textile industries in the southern United States were evaluated based on cost benefit analysis. The se studies represented four types of solar systems: flat plate, evacuated tube, parabolic trough, and shallow solar pond. Based on the net present value and payback period criteria, the flat plate system in Georgia and the evacuated tube system in North Carolina (augmenting a residual oil system) appear to be economically feasible. The shallow solar pond systems in North Carolina have a payback of less than three years; however, the net present value is negative. A sensitivity analysis indicated the net present value to be extremely sensitive to tax credits, fuel escalation price projections, and collector cost. Therefore, it was recommended that these parameters be closely observed so the system could be reevaluated when a change occurs. Although the evacuated tube and parabolic trough systems did not appear economically feasible, based on the current fuel price projections, they would be a viable alternative within five years.

The analysis assumes all systems would be installed after 1981 and thus take advantage of the new depreciation schedule as outlined in the Economic Recovery Tax Act of 1981. Depreciation schedules prior to this act were based on the "useful life" concept and could employ one of the three depreciation methods. Irrespective of the method chosen, a positive net present value would not have existed in any one of the nine case studies. Thus, the new depreciation schedule improves all systems under consideration. 
1. J.L. Clark, et al., "Georgia Solar Industrial Process Heat Project," SSEC-1125-C-430-0030, Engineering Experiment Station, Georgia Institute of Technology, Atlanta, Georgia, October 1980.

2. H.M. Eckerlin, et al:, "Solar Industrial Process Heat for the Textile Industry," SSEC-1125-C-430-0031, Industrial Extension Service, North Carolina State University, Raleigh, North Carolina, February 1981.

3. P.E. Jenkins, "Texas Solar Industrial Process Heat Project," SSEC-1125-C-430-0023, Texas A\&M University, College Station, Texas, September 1980.

4. Eckerlin, op. cit., p. A-50.

5. R.B. Edelstein, "Solar Thermal Cost Goals," Proceedings of the ASME Solar Energy Division Third Annual Conference, Reno, Nevada, April 27 - May 1, 1981 , pp. 495-503.

6. Data Resources, Inc., Energy Review, Lexington, MA, 1980.

7. F.S. Worthy, "The 500 - The Fortune Directory of the Largest U.S. Industrial Corporations," Fortune, Vol. 103, No. 9, May 4, 1981, pp. 322-349.

8. Public Law 97-34.

9. D. E. Ball, "The Economic Recovery Act of 1981 and Tax Policies for Commercial Solar Applications," Southern Solar Energy Center, Atlanta, Georgia, December 1981 .

10. Chase Econometrics Associates, Inc., Energy Analysis Quarterly, Bala Cynwyd, PA, May 1981.

11. Data Resources, Inc., op. cit.

12. Edelstein, op. cit., p. 499.

13. "Energy Price Trends," Energy Users News, Vol. 6, No. 23, June 8, 1981, p. 13.

14. "Views on Price Outlook Analyzed By Region," Energy Users News, Vol. 6, No. 3, July 27, 1981, p. 24.

15. "Energy Price Trends," op. cit., p. 13.

16. "Views on Price Outlook....," op. cit., p. 24.

17. D.H. Gustashaw, "Operations Procedures and User Instructions for WOOD 4 Version 2, a Computer Program for Economic Analysis of Industrial Wood Energy Systems," Working Paper 044WP, Southern Solar Energy Center, Atlanta, Georgia, August 1987. 
WOOD 4 Version 217 is maintained by the Southern Solar Energy Center. It is an interactive computer program originaliy designed to determine the economic attractiveness of an investment in a wood energy system; it was later adapted for other alternative energy systems. The economic indicators generated are based on life-cycle costs resulting from a comparison of an al ternative energy system to an energy system fired with oil, gas, or coal. The data included in the life cycle cost routine are the fixed and variable costs normally associated with this type of industrial investment. These data are initialized at the beginning of the program. WOOD 4 Version 2 is equipped to handle different analyses and has editing and iteration features. These features allow the user to perform a wide range of sensitivities under different conditions.

WOOD 4 Version 2 was modified to incorporate the new depreciation tax schedule resulting from the Economic Recovery Tax Act of 1981. It now has a provision whereby the fuel escalation rates can vary in five-year increments instead of a constant escalation factor for the system's life.

The following example is an illustration of the printout of a typical run. 
HET 178017

FLEASE SI6H DH--K.EK, A23E 6 DE

81 11113: 15:26:53:

EASTERH EYSERMET CENTER SHBOS MES

PASSWERI

DronIRad

TERAIIPIFL:

6. TTY

YEUR PASSLIDRI HAS MDT CHANGED IN GO DAYS, FLEASE CHANGE YDUR FASSHDRI:

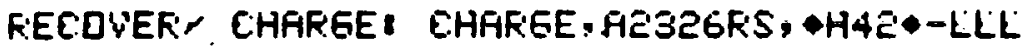

RERIIY:

NQTIEE - FLL USERS FLS TYFE EXFLAIN, MELIJAY:

EFTEH

SFELE: O:

TEET, TRYS, FERPAT

ITEYS

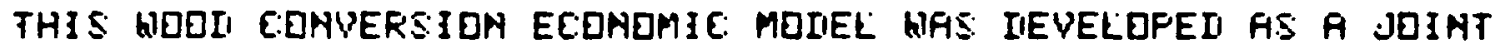
FR:D.JEET FY THE ENGIMEERIME EXFFERIMENT STTATIDH DF GEDR6IA TEEH

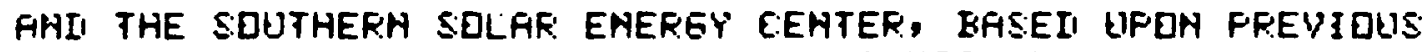

hIERK. DF THE NEW ENGLANI REGIOHFL COMMISSIOH:

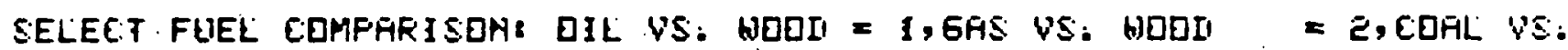
HODI $=3 \% 2$

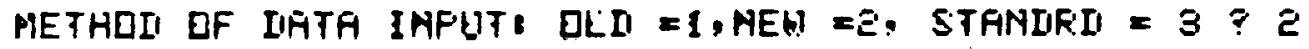

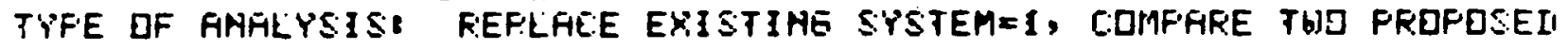
SYSTEMS: 2 ? 1

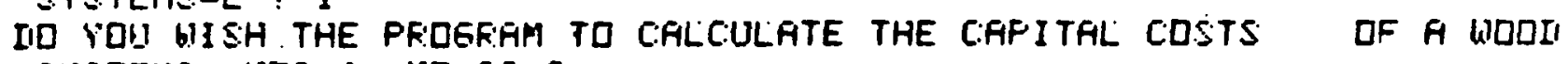
SYSTEMT YES=1, NQD=E? $\varepsilon$ 
INFUT - IATTA:

\begin{tabular}{|c|c|c|}
\hline 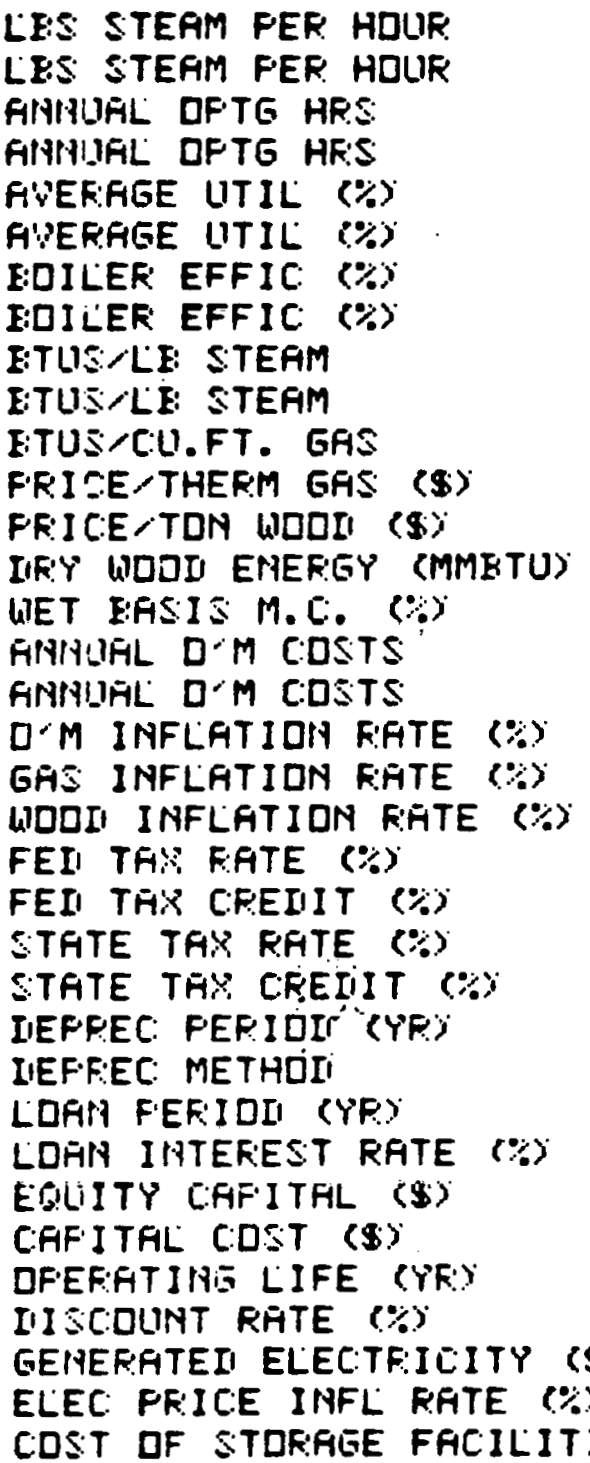 & $\begin{array}{l}\text { (GAS) } \\
\text { (WIDDII) } \\
\text { (GAS) } \\
\text { (WDDI) } \\
\text { (GAS) } \\
\text { (WDDII) } \\
\text { (GFS) } \\
\text { (WDDII) } \\
\text { (GAS) } \\
\text { (WDDII) }\end{array}$ & 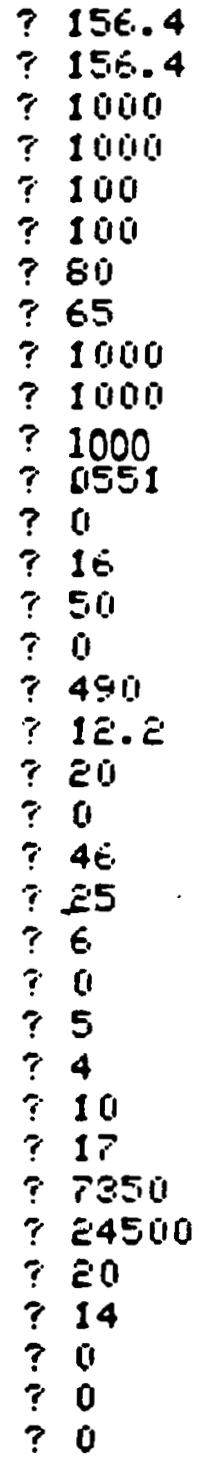 \\
\hline
\end{tabular}

IIATA LOAGIEII

NAME DF FFCILITY CUF TO 24 CHARS.) ? TEC2005F

NEXT CHOICE? 2

DUTFUT? TERMINFL $=0$. PRINTER $=1 ?$ i 
TECZOOSA

ERSE C:ASE IIATA:

LES STEAM FER HOUR

(GAS) : 156.40

LES STEAM FER HDUR.

AHHLIAL DFTE HRS

FINIUUAL DFTG HRS

AVERFGE UTIL (\%)

FUER:AGE UTIL (\%

EDILER EFFIC (\%)

E:DILER EFFIC (\%)

E:TUS/L STEAM

ITUIS:-LB S:TEAM

ETUIS×EUI:FT: GAS

FRIICEXTHERM EAS RS;

FF:IC:E $>$ TD: 1 WODI (\$)

IFY' WDOI ENEEREY (MMETUY)

WET ERSIS M.L: KW

GANIEIAL D'M E:DSTS

ATIN!IFL D-M C:DS:TS

(INDOI):
(GAS) :

156.40

(WDDI) :

1000.00

100.00

100.00

$\begin{array}{ll}\text { (GAS) : } & 80.00 \\ \text { (WIDOI) : } & 65.00 \\ \text { (GAS) } & 1000.00\end{array}$

$\begin{array}{ll}\text { (GAS) : } & 80.00 \\ \text { (UIDOI) : } & 65.00 \\ \text { (GAS) } & 1000000\end{array}$

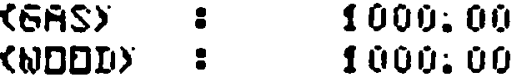

$1000: 00$

$: 55$

0.00

16.00

50:00

$0: 00$

490:00

18: 80

E०: 00

$0: 00$

4E: 00

E.5: 010

E. 00

$0: 00$

5: 010

IIEFREC FERIOI (YR)

IIEFR'EE: METHOU

LDANA FERIOII (YR')

LDAN INTEREST RATE $R \%$

EQUIITY C:FFITRL (S)

EAFITM- EDST (S)

DFERITINIS LIFE (YR)

IIJSCDUNT RATE (\%)

GENERATEII ELECTRICITY (\$PYR)

ELEE: FRICE INFL REATE (\%)

COST DF STORFIE FFEILITIES

Fi: METHDD

10:00

18:00

F $350: 010$

24500.00

20.00

14. 011

$0: 00$

0.00

0. 00

ESTIMATED ANAUAL CONSUMETIDN \& CDSTS

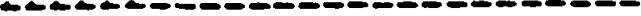

AIINIIFL EAS CDNSUMFTIDN: 195500: C:L:FT. /YR

FIAN!IFL CDST FT $\$$.5E FER THERM: $\$$ IOFP:EI

FNNLIFL WICT. CONSUMFTIDN: S0: TUNS

ARINIAL CUST AT $\$ 0.09$ FER TDN: $\$$ S 0.00

IID YOU WISH TO USE A YARIAELE FLIEL INFLATION RATE ? YES $=1 \quad N D=2$

71

IHFIIT INFLATIDIN RATE FDF YEAR:S 1 THFU 5

$\div 19.4$

INFIIT INFLATIDN RETE FDR YEARS 6 THELI 10

$? 19.4$

IHFIIT INFLATIDM FIATE FDF YEAFS 11 THFUI 15

$? 16.7$

INF.IJT INFLATIDN RATE FDR YEARS IE THFU 20

? 16.7 
COMPARISOH DF RLTERAATIVE FUELS

- - -

CASH FLDW RNALYSIS WITH FINANEINIS

(THDUSANIS DF IOLLFF:S)

YEARS:

24.5
INSTALLATIDA
$217.2)$

THWENTIDNFL CODSTS

1.1

1.3

1.5

1.8

2. 2

ILLI CDSTS

0. 0

0.0

0.0

0.0

0.0

BEAAEFATEI ELECTRICITY

0.0

0.0

0.0

0.0

0.0

FUEL SAVIHES

1. I

1.3

1.5

1.8

$\varepsilon \cdot \varepsilon$

FIIIIITIDAFL OI:M

.5

.5

.$\epsilon$

.7

.8

IIEF'FEE:IATIDN

3.7

5.4

5.1

5.1

5.1

I HTEFEST

E. g

E. .7

2. $\epsilon$

2.4

E. E

FFETAY INE:DME

$-5.9$

$-7.4$

$-\epsilon . \varepsilon$

$-6.4$

$-5.9$

THEES FAYAELE

STFTE

$-.4 \quad-.4$

$-.4$

$-.4$

$-.4$

FEIJE:FL'

$-2.6 \quad-3.2$

$-\dot{E} .9$

$-2: 8$

$-2.6$

THX. CFEIITS:

(6.1)

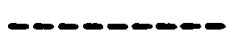

IUET EAF:NINES-RFTER

TA:?

$-3.0$

$-3.7$

$-3.5$

$-3.2$

$-3.0$

AIII IIEFRECIATIDIB

9.7

5.4

5.1

5. 1

5.1

TIEIULT LOAN FAYMENT

.7

I. 0

1.2

1.4

IIET C̈A亏H FLLW

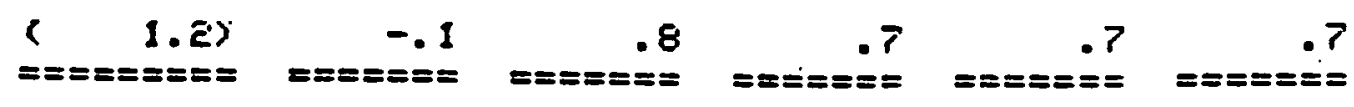




\section{SUESEQUENT PLANAING CYCLES}

(THQLISARIS DF IDLLARS)

CDRYENTIOAFL COSTS

WDI CDSTS

GEMEFATEI ELECTRICITY

FUEL SAUINGS

FIIIITIONFL OSM

IIEFFECIATIDN

IPTEREST

FFETAN IHCDME

TARES FATYAELL

STATE

FEIIERFIL

MET EAFNINGS-FFTER.

TAX:

FIII IIEFRECIATIDN

IEIIUCT LEFIN PAYMENT

NET [:ASH F'PN)

YEFFS

$6-10 \quad 11-1516-20$

$\begin{array}{rrr}19.2 & 35.2 & 76.2 \\ 0.0 & 11.0 & 0.0 \\ 0.0 & 0.0 & 0.0 \\ 19.2 & 35.2 & 76.2 \\ 5.6 & 9.9 & 17.6 \\ 0.0 & 0.0 & 0.0 \\ 5.9 & 0.0 & 0.0\end{array}$

7.8 $\quad 25.3 \quad 58.6$

$\begin{array}{lll}.5 & 1.5 & 3.5\end{array}$

$3.4 \quad 10.9 \quad 25.3$

\begin{tabular}{rrr}
3.9 & 12.8 & 29.7 \\
0.0 & 0.0 & 0.0 \\
18.0 & 0.0 & 0.0 \\
\hline-8.0 & 18.8 & 89.7 \\
$==8==0$ & $===0=0$ & $==8==0$
\end{tabular}


ECDIOMIC VFLUES OF WDOL FLIEL FLTERNFTIVE

CASH FFIEACK FERIDI DF INITIFL INUESTMENT = Ë.T YEARS

FAYBALK OF TOTAL INUESTMENT = 13.0 YEAF:S CEUMULATIVE

C.ASH FLDW IS SUIFFICIENT TO FECDWER INITIFL

INUESTMEITT FNI REMAINING LOAN BALANCE)

HET FRESENT VALUE $=$ 2.T (IISCDUNTEI FT $14.000 \%$ )

IMTERIMAL RATE DF RETLIR:N $=24 . \%$

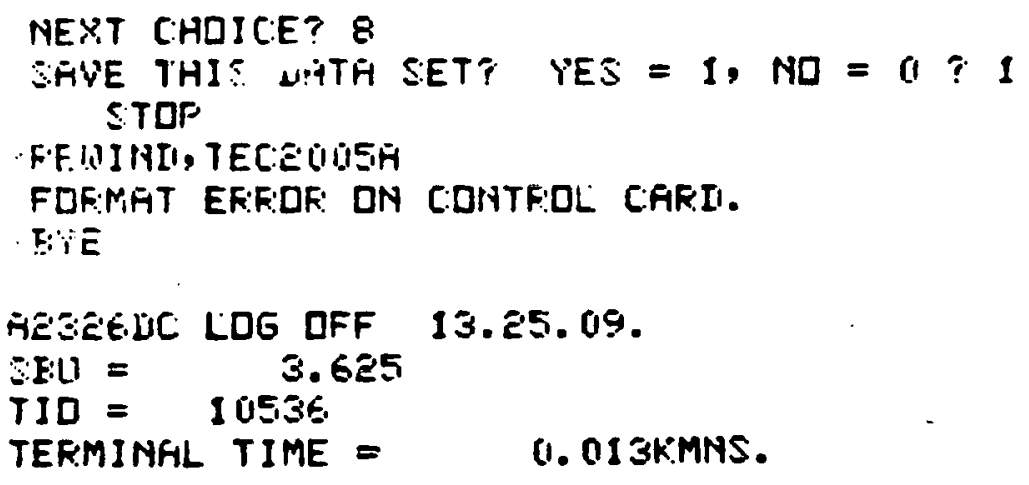




\section{APPENDIX B}

\section{NET CASH FLOW TABLES}

The net cash flow for the seven case studies is illustrated in Tables VI through XIII. The cash flow for Case Study I, System I appears in Table III on page 9 . 


\section{TABLE VI}

Net Cash Flow For Case Study I, System II

(Thousands of Current Year Dollars)

\begin{tabular}{|c|c|c|c|c|c|c|c|c|c|}
\hline CATEGORY & 0 & 1 & 2 & 3 & 4 & 5 & $6-10$ & $11-15$ & $16-20$ \\
\hline Fuel Savings & & 3.2 & 3.8 & 4.6 & 5.4 & 6.5 & 57.0 & 104.4 & 226.0 \\
\hline $\begin{array}{l}\text { Deductible Expenses: } \\
\text { 0\&M } \\
\text { Interest Pmt. } \\
\text { Depreciation }\end{array}$ & & $\begin{array}{r}1.4 \\
8.2 \\
10.5\end{array}$ & $\begin{array}{r}1.6 \\
7.8 \\
15.4\end{array}$ & $\begin{array}{r}1.8 \\
7.4 \\
14.7\end{array}$ & $\begin{array}{r}2.0 \\
6.8 \\
14.7\end{array}$ & $\begin{array}{r}2.2 \\
6.2 \\
14.7\end{array}$ & $\begin{array}{r}15.9 \\
16.8 \\
0.0\end{array}$ & $\begin{array}{r}28.2 \\
0.0 \\
0.0\end{array}$ & $\begin{array}{r}50.2 \\
0.0 \\
0.0\end{array}$ \\
\hline Taxable Income: & & -16.9 & -21.0 & -19.3 & -18.1 & -16.6 & 24.3 & 76.2 & 175.8 \\
\hline $\begin{array}{l}\text { Income Taxes Payable: } \\
\text { State } \\
\text { Federal }\end{array}$ & & $\begin{array}{l}-1.0 \\
-7.3\end{array}$ & $\begin{array}{l}-1.3 \\
-9.1\end{array}$ & $\begin{array}{l}-1.2 \\
-8.3\end{array}$ & $\begin{array}{l}-1.1 \\
-7.8\end{array}$ & $\begin{array}{l}-1.0 \\
-7.2\end{array}$ & $\begin{array}{r}1.5 \\
10.5\end{array}$ & $\begin{array}{r}4.6 \\
32.9\end{array}$ & $\begin{array}{l}10.5 \\
76.0\end{array}$ \\
\hline Loan Principal & & 2.0 & 2.4 & 2.9 & 3.4 & 4.0 & 34.3 & 0.0 & 0.0 \\
\hline Net Cash Flow** & $-3.5^{\star}$ & -.1 & 2.3 & 2.1 & 2.1 & 2.2 & -21.9 & 38.7 & 89.2 \\
\hline
\end{tabular}

$\star$ Equipment Cost - Loan Proceeds - Tax Credits $=(70.0-49.0-17.5)=3.5$

* Depreciation is a tax accounting procedure and not an actual expense; therefore, net cash flow equals fuel savings less $0 \& M$ expense, taxes, and loan service. 


\section{TABLE VII}

Net Cash Flow For Case Study II

(Thousands of Current Year Dollars)

\begin{tabular}{|c|c|c|c|c|c|c|c|c|c|c|}
\hline CATEGORY & YEAR: & : 0 & 1 & $?$ & 3 & 4 & 5 & $6-10$ & $11-15$ & $16-20$ \\
\hline Fuel Savings & & & 5.1 & 6.1 & 7.3 & 8.7 & 10.3 & 90.8 & 166.1 & 359.6 \\
\hline $\begin{array}{l}\text { Deductible Expens } \\
\text { 0\&M } \\
\text { Interest Pmt. } \\
\text { Depreciation }\end{array}$ & & & $\begin{array}{r}6.8 \\
39.6 \\
50.9\end{array}$ & $\begin{array}{r}7.6 \\
37.8 \\
74.6\end{array}$ & $\begin{array}{r}8.5 \\
35.7 \\
71.3\end{array}$ & $\begin{array}{r}9.6 \\
33.1 \\
71.3\end{array}$ & $\begin{array}{l}10.8 \\
30.1 \\
71.3\end{array}$ & $\begin{array}{r}77.0 \\
81.6 \\
0.0\end{array}$ & $\begin{array}{r}136.8 \\
0.0 \\
0.0\end{array}$ & $\begin{array}{r}243.3 \\
0.0 \\
0.0\end{array}$ \\
\hline Taxable Income: & & & -92.2 & -114.0 & -108.2 & -105.3 & -101.7 & 67.8 & 29.3 & 116.3 \\
\hline $\begin{array}{l}\text { Income Taxes Pay } \\
\text { State } \\
\text { Federal }\end{array}$ & ble: & & $\begin{array}{r}-5.5 \\
-39.9\end{array}$ & $\begin{array}{r}-6.8 \\
-49.3\end{array}$ & $\begin{array}{r}-6.5 \\
-46.8\end{array}$ & $\begin{array}{r}-6.3 \\
-45.5\end{array}$ & $\begin{array}{r}-6.1 \\
-44.0\end{array}$ & $\begin{array}{r}4.1 \\
29.3\end{array}$ & $\begin{array}{r}1.8 \\
12.7\end{array}$ & $\begin{array}{r}7.0 \\
50.3\end{array}$ \\
\hline Loan Principal & . & & 9.9 & 11.7 & 13.9 & 16.4 & 19.5 & 166.1 & 0.0 & 0.0 \\
\hline Net Cash Flow & & $-17.0 *$ & * -5.8 & 5.1 & 2.4 & 1.4 & 0.1 & -200.5 & 14.9 & 59.0 \\
\hline
\end{tabular}

* Equipment Cost - Loan Proceeds - Tax Credits $=(339.3-237.5-84.8)=17.0$

** Depreciation is a tax accounting procedure and not an actual expense; therefore, net cash flow equals fuel savings less 0 \& $M$ expense, taxes, and loan service. 
TABLE VIII

Net Cash Flow For Case Study III

(Thousands of Current Year Dollars)

\begin{tabular}{|c|c|c|c|c|c|c|c|c|c|}
\hline CATEGORY & YEAR: & 0 & 2 & 3 & 4 & 5 & $6-10$ & $11-15$ & $16-20$ \\
\hline Fuel Savings & & 8.3 & 9.9 & 11.8 & 14.1 & 16.8 & 147.5 & 270.0 & 584.4 \\
\hline $\begin{array}{l}\text { Deductible Expen } \\
\text { 0\&M } \\
\text { Interest Pmt. } \\
\text { Depreciation }\end{array}$ & & $\begin{array}{l}10.9 \\
63.5 \\
81.6\end{array}$ & $\begin{array}{r}12.2 \\
60.6 \\
119.7\end{array}$ & $\begin{array}{r}13.7 \\
57.1 \\
\cdot 114.2\end{array}$ & $\begin{array}{r}15.4 \\
53.1 \\
114.2\end{array}$ & $\begin{array}{r}17.2 \\
48.2 \\
114.2\end{array}$ & $\begin{array}{r}123.4 \\
130.8 \\
0.0\end{array}$ & $\begin{array}{r}219.4 \\
0.0 \\
0.0\end{array}$ & $\begin{array}{r}390.1 \\
0.0 \\
0.0\end{array}$ \\
\hline Taxable Income: & & -147.7 & -182.6 & -173.3 & -168.6 & -162.9 & -106.6 & 50.6 & 194.4 \\
\hline $\begin{array}{l}\text { Income Taxes Pay } \\
\text { State } \\
\text { Federal }\end{array}$ & le: & $\begin{array}{r}-8.9 \\
-63.9\end{array}$ & $\begin{array}{l}-11.0 \\
-79.0\end{array}$ & $\begin{array}{l}-10.4 \\
-74.9\end{array}$ & $\begin{array}{l}-10.1 \\
-72.9\end{array}$ & $\begin{array}{r}-9.8 \\
-70.4\end{array}$ & $\begin{array}{r}-6.4 \\
-46.1\end{array}$ & $\begin{array}{r}3.0 \\
21.9\end{array}$ & $\begin{array}{l}11.7 \\
84.0\end{array}$ \\
\hline Loan Principal & & 15.9 & 18.8 & 22.3 & 26.4 & 31.2 & 266.3 & 0.0 & 0.0 \\
\hline Net Cash Flow** & & $-27.2 *-9.3$ & 8.2 & 4.0 & 2.3 & 0.4 & -320.4 & 25.7 & 98.7 \\
\hline
\end{tabular}

* Equipment Cost - Loan Proceeds - Tax Credits $=(543.9-380.7-136.0)=27.2$

* Depreciation is a tax accounting procedure and not an actual expense; therefore, net cash flow equals fuel savings. less 0 \& $M$ expense, taxes, and loan service. 
TABLE IX

Net Cash Flow For Case Study IV, System I

(Thousands of Current Year Dollars)

\begin{tabular}{|c|c|c|c|c|c|c|c|c|}
\hline CATEGORY & 0 & 1 & 2 & 3 & 4 & 5 & $6-10$ & $11-15$ \\
\hline Fuel Savings & & 5.5 & 6.3 & 7.3 & 8.4 & 9.7 & 76.5 & 149.0 \\
\hline $\begin{array}{l}\text { Deductible Expenses: } \\
\text { 0\&M } \\
\text { Interest Pmt. } \\
\text { Depreciation }\end{array}$ & & $\begin{array}{l}2.6 \\
14.9 \\
19.2\end{array}$ & $\begin{array}{r}2.9 \\
14.3 \\
28.2\end{array}$ & $\begin{array}{r}3.2 \\
13.4 \\
26.9\end{array}$ & $\begin{array}{r}3.6 \\
12.5 \\
26.9\end{array}$ & $\begin{array}{r}4.1 \\
11.3 \\
26.9\end{array}$ & $\begin{array}{r}29.0 \\
30.8 \\
0.0\end{array}$ & $\begin{array}{r}51.6 \\
0.0 \\
0.0\end{array}$ \\
\hline Taxable Income: & & -31.2 & -39.0 & -36.3 & -34.6 & -32.6 & 16.7 & 97.4 \\
\hline $\begin{array}{l}\text { Income Taxes Payable: } \\
\text { State }\end{array}$ & & -1.9 & -2.3 & -2.2 & -2.1 & -2.0 & 1.0 & 5.8 \\
\hline Federal & & -13.5 & -16.9 & -15.7 & -14.9 & -14.1 & 7.2 & 42.1 \\
\hline Loan Principal & & 3.7 & 4.4 & 5.2 & 6.2 & 7.3 & 62.7 & 0.0 \\
\hline Net Cash Flow** & $1.7 \star$ &.- .4 & 3.9 & 3.2 & 3.1 & 3.0 & -54.2 & 49.4 \\
\hline
\end{tabular}

* Equipment Cost - Loan Proceeds - Tax Credits $=(128.0-89.6-40.1)=1.7$

* Depreciation is a tax accounting procedure and not an actual expense; therefore, net cash flow equals fuel savings less 0 \& $M$ expense, taxes, and loan service. 
TABLE $X$

Net Cash Flow For Case Study IV, System II

(Thousands of Current Year Dollars)

\begin{tabular}{|c|c|c|c|c|c|c|c|c|}
\hline CATEGORY & 0 & 1 & 2 & 3 & 4 & 5 & $6-10$ & $11-15$ \\
\hline Fuei Savings & & 10.9 & 12.6 & 14.6 & 16.9 & 19.5 & 153.2 & 298.5 \\
\hline $\begin{array}{l}\text { Deductible Expenses: } \\
\text { 0\&M } \\
\text { Interest Pmt. } \\
\text { Depreciation }\end{array}$ & & $\begin{array}{r}5.1 \\
29.9 \\
38.4\end{array}$ & $\begin{array}{r}5.7 \\
28.5 \\
56.3\end{array}$ & $\begin{array}{r}6.4 \\
26.9 \\
53.8\end{array}$ & $\begin{array}{r}7.2 \\
25.0 \\
53.8\end{array}$ & $\begin{array}{r}8.1 \\
22.7 \\
53.8\end{array}$ & $\begin{array}{r}58.1 \\
61.6 \\
0.0\end{array}$ & $\begin{array}{r}103.3 \\
0.0 \\
0.0\end{array}$ \\
\hline Taxable Income: & & -62.5 & -77.9 & -72.5 & -69.1 & -65.1 & 33.6 & 195.3 \\
\hline $\begin{array}{l}\text { Income Taxes Payable: } \\
\text { State }\end{array}$ & & -3.7 & -4.7 & -4.4 & -4.1 & -3.9 & 2.0 & 11.7 \\
\hline Federal & & -27.0 & -33.7 & -31.4 & -29.9 & -28.1 & 14.5 & 84.4 \\
\hline Loan Principal & & 7.5 & 8.8 & 10.5 & 12.4 & 14.7 & 125.3 & 0.0 \\
\hline Net Cash Flow** & $-4.9 \star$ & -.8 & 7.9 & 6.5 & 6.3 & 6.0 & -108.3 & 99.1 \\
\hline
\end{tabular}

* Equipment Cost - Loan Proceeds - Tax Credits $=(256.0-179.2-71.9)=4.9$

* Depreciation is a tax accounting procedure and not an actual expense; therefore, net cash flow equals fuel savings less 0 \& $M$ expense, taxes, and loan service. 
TABLE XI

Net Cash Flow For Case Study V

(Thousands of Current Year Dollars)

\begin{tabular}{|c|c|c|c|c|c|c|c|c|c|}
\hline CATEGORY & 0 & 1 & 2 & 3 & 4 & 5 & $6-10$ & $11-15$ & $16-20$ \\
\hline Fuel Savings & & 4.0 & 4.6 & 5.3 & 6.1 & 7.1 & 55.6 & 108.3 & 217.8 \\
\hline $\begin{array}{l}\text { Deductible Expenses: } \\
\text { 08M } \\
\text { Interest Pmt. } \\
\text { Depreciation }\end{array}$ & & $\begin{array}{r}1.8 \\
10.5 \\
13.5\end{array}$ & $\begin{array}{l}2.0 \\
10.0 \\
19.8\end{array}$ & $\begin{array}{r}2.3 \\
9.5 \\
18.9\end{array}$ & $\begin{array}{r}2.5 \\
8.8 \\
18.9\end{array}$ & $\begin{array}{r}2.9 \\
8.0 \\
18.9\end{array}$ & $\begin{array}{r}20.4 \\
21.6 \\
0.0\end{array}$ & $\begin{array}{r}36.3 \\
0.0 \\
0.0\end{array}$ & $\begin{array}{r}64.5 \\
0.0 \\
0.0\end{array}$ \\
\hline Taxable Income: & & -21.8 & -27.3 & -25.3 & -24.1 & -22.7 & 13.5 & 72.0 & 153.3 \\
\hline $\begin{array}{l}\text { Income Taxes Payable: } \\
\text { State } \\
\text { Federal }\end{array}$ & & $\begin{array}{l}-1.3 \\
-9.4\end{array}$ & $\begin{array}{r}-1.6 \\
-11.8\end{array}$ & $\begin{array}{r}-1.5 \\
-11.0\end{array}$ & $\begin{array}{r}-1.4 \\
-10.4\end{array}$ & $\begin{array}{l}-1.4 \\
-9.8\end{array}$ & $\begin{array}{r}.8 \\
5.8\end{array}$ & $\begin{array}{r}4.3 \\
31.1\end{array}$ & $\begin{array}{r}9.2 \\
66.3\end{array}$ \\
\hline Loan Principal & & 2.6 & 3.1 & 3.7 & 4.4 & 5.2 & 44.1 & 0.0 & 0.0 \\
\hline Net Cash Flow*t & $3.5^{\star}$ & $+\quad-.2$ & 2.9 & 2.4 & 2.3 & 2.2 & -37.2 & 36.5 & 77.8 \\
\hline
\end{tabular}

* Equipment Cost - Loan Proceeds - Tax Credits $=(90.0-63.0-30.5)=3.5$

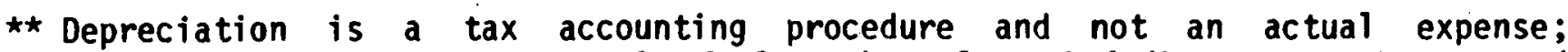
therefore, net cash flow equals fuel savings less 0 \& $M$ expense, taxes, and loan service. 


\section{TABLE XII}

Net Cash Flow For Case Study VI.

(Thousands of Current Year Dollars)

\begin{tabular}{|c|c|c|c|c|c|c|c|c|}
\hline CATEGORY & 1 & 2 & 3 & 4 & 5 & $6-10$ & $11-15$ & $16-20$ \\
\hline Fuel Savings & 4.1 & 4.9 & 5.8 & 7.0 & 8.3 & 73.1 & 133.8 & 289.6 \\
\hline $\begin{array}{l}\text { Deductible Expenses: } \\
\text { 0\&M } \\
\text { Interest Pmt. } \\
\text { Depreciation }\end{array}$ & $\begin{array}{r}3.9 \\
22.5 \\
28.9\end{array}$ & $\begin{array}{r}4.3 \\
21.4 \\
42.4\end{array}$ & $\begin{array}{r}4.8 \\
20.2 \\
40.4\end{array}$ & $\begin{array}{r}5.4 \\
18.8 \\
40.4\end{array}$ & $\begin{array}{r}6.1 \\
17.1 \\
40.4\end{array}$ & $\begin{array}{r}43.7 \\
46.3 \\
0.0\end{array}$ & $\begin{array}{r}77.6 \\
0.0 \\
0.0\end{array}$ & $\begin{array}{r}138.1 \\
0.0 \\
0.0\end{array}$ \\
\hline Taxable Income: & -51.1 & -63.2 & -59.7 & -57.7 & -55.3 & -16.8 & 56.2 & 151.6 \\
\hline $\begin{array}{l}\text { Income Taxes Payable } \\
\text { State } \\
\text { Federal }\end{array}$ & $\begin{array}{r}0.0 \\
-23.5\end{array}$ & $\begin{array}{r}0.0 \\
-29.1\end{array}$ & $\begin{array}{r}0.0 \\
-27.4\end{array}$ & $\begin{array}{r}0.0 \\
-26.5\end{array}$ & $\begin{array}{r}0.0 \\
-25.4\end{array}$ & $\begin{array}{r}0.0 \\
-7.7\end{array}$ & $\begin{array}{r}0.0 \\
25.8\end{array}$ & $\begin{array}{r}0.0 \\
69.7\end{array}$ \\
\hline Loan Principal & 5.6 & 6.7 & 7.9 & 9.3 & 11.0 & 94.2 & 0.0 & 0.0 \\
\hline Net Cash Flow** & $-9.6 *-4.3$ & 1.6 & .3 & 0.0 & -.5 & -103.3 & 30.3 & 81.8 \\
\hline
\end{tabular}

* Equipment Cost - Loan Proceeds - Tax Credits $=(192.5-134.8-48.1)=9.6$

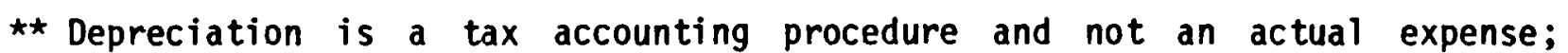
therefore, net cash flow equals fuel savings less 0 \& $M$ expense, taxes, and loan service. 
TABLE XIII

Net Cash Flow For Case Study VII

(Thousands of Current Year Dollars)

\begin{tabular}{|c|c|c|c|c|c|c|c|c|}
\hline CATEGORY & 0 & 2 & 3 & 4 & 5 & $6-10$ & $11-15$ & $16-20$ \\
\hline Fuel Savings & 3.4 & 4.0 & 4.8 & 5.7 & 6.8 & 60.0 & 109.9 & 237.9 \\
\hline $\begin{array}{l}\text { Deductible Expenses: } \\
\text { 08M } \\
\text { Interest Pmt. } \\
\text { Depreciation }\end{array}$ & $\begin{array}{r}3.0 \\
17.5 \\
22.5\end{array}$ & $\begin{array}{r}3.4 \\
16.7 \\
33.0\end{array}$ & $\begin{array}{r}3.8 \\
15.8 \\
31.5\end{array}$ & $\begin{array}{r}4.2 \\
14.6 \\
31.5\end{array}$ & $\begin{array}{r}4.8 \\
13.3 \\
31.5\end{array}$ & $\begin{array}{r}34.0 \\
36.1 \\
0.0\end{array}$ & $\begin{array}{r}60.5 \\
0.0 \\
0.0\end{array}$ & $\begin{array}{r}107.6 \\
0.0 \\
0.0\end{array}$ \\
\hline Taxable Income: & -39.7 & -49.1 & -46.2 & -44.6 & -42.7 & -10.0 & 49.4 & 130.3 \\
\hline $\begin{array}{l}\text { Income Taxes Payable: } \\
\text { State } \\
\text { Federal }\end{array}$ & $\begin{array}{r}0.0 \\
-18.2\end{array}$ & $\begin{array}{r}0.0 \\
-22.6\end{array}$ & $\begin{array}{r}0.0 \\
-21.3\end{array}$ & $\begin{array}{r}0.0 \\
-20.5\end{array}$ & $\begin{array}{r}0.0 \\
-19.6\end{array}$ & $\begin{array}{r}0.0 \\
-4.6\end{array}$ & $\begin{array}{r}0.0 \\
22.7\end{array}$ & $\begin{array}{r}0.0 \\
59.9\end{array}$ \\
\hline Loan Principal & 4.4 & 5.2 & 6.1 & 7.3 & 8.6 & 73.4 & 0.0 & 0.0 \\
\hline Wet Cash Flow** & $-7.5^{\star}-3.3$ & 1.3 & .4 & .1 & -.2 & -78.9 & 26.7 & 70.4 \\
\hline
\end{tabular}

$\star$ Equipment Cost - Loan Proceeds - Tax Credits $=(150.0-105.0-37.5)=7.5$

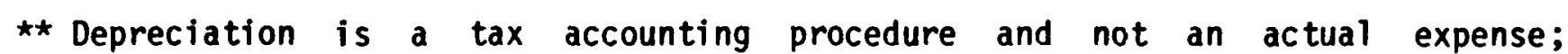
therefore, net cash flow equals fuel savings less 0 \& $M$ expense, taxes, and loan service. 